University of Michigan Law School

University of Michigan Law School Scholarship Repository

Books

Faculty Scholarship

1915

Corporations and Express Trusts: As Business Organizations

Horace La Fayette Wilgus

University of Michigan Law School

Available at: https://repository.law.umich.edu/books/35

Follow this and additional works at: https://repository.law.umich.edu/books

Part of the Business Organizations Law Commons, Legislation Commons, and the State and Local Government Law Commons

Recommended Citation

Wilgus, Horace La Fayette, Corporations and Express Trusts: as Business OrganizationsAnn Arbor 1915

This Book is brought to you for free and open access by the Faculty Scholarship at University of Michigan Law School Scholarship Repository. It has been accepted for inclusion in Books by an authorized administrator of University of Michigan Law School Scholarship Repository. For more information, please contact mlaw.repository@umich.edu. 


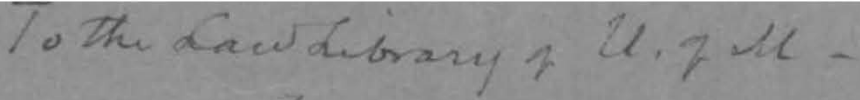

$$
\begin{aligned}
& \text { Arov } \\
& \text { NL.Nreguo }
\end{aligned}
$$

\title{
CORPORATIONS AND EXPRESS TRUSTS
}

\section{AS BUSINESS ORGANIZATIONS}

\section{BY, to \\ H. L. WILGUS}

PROFEsGOR ON LAW IN THE UNIVERSITY OF MrCHIOAN

\author{
REPRINTED FROM MICHIGAN LAW RFVIEW, VOLUME XIII, NOS. 2 AND 3 , \\ DECBMBRR, I 914 , AND JANUARY, I 915
}




\section{CORPORATIONS AND EXPRESS TRUSTS AS BUSINESS ORGANIZATIONS.*

\author{
Advantages ${ }^{\mathrm{I}}$ Claimed.
}

D

RESIDE NT BUTLER of Columbia University is reported to

have said in an address before the New York Chamber of

Commerce in 1911, that "the limited liability corporation is the greatest single discovery of modern times, whether you judge it by its social, by its ethical, by its industrial, or, in the long run- after we understand it and know how to use it,-by its political, effects." 1 - In 1912, in a paper submitted to the Tax Commissioner of Massaclmsetts, Alfred D. CHANDLER, of the Boston Bar, said "Express Trusts, whether created under wills, deeds of settlement, assignments Jor the benefit of creditors, receiverships, or by special declarations of trust, to manage property or carry on business, are neither corporations nor joint stock companies, nor partnerships, but they employ a distinct and the highest known method of administration."3

The latest Statistical Abstract shows that in 1913, there were in the United States 305,336 corporations, with over $\mathbf{\$ 9 6 , 0 0 0 , 0 0 0 , 0 0 0}$ of stock and bonds, with an income of over $\$ 3,800,000,000$, and pay- ing a tax to the Federal government of over $\$ 35,000,000$. The stock and bonds together represent nearly or quite two thirds of the wealth of the whole country. In 4 years, 1909-1913, the number of corporations increased over 40,000 , and the stock and bonds over

$\$ 12,000,000,000$. $^{8}$

- Address before the North Dakota State Bar Association, Sept. 17, 1914

${ }^{1}$ The Government and the Corporations, by Francia Lynde Stetson, ${ }_{10}$ Atl. M., p. 27, 32 (July, 19u) quoting from Pres. Butler.

${ }^{1}$ Express Trusts under the Common Law, by Alfred Chandler, p. 26. Little, Brown \& Co. 1912.

- United States Statistical Abstract, 1913, p. 600. 
In conservative Massachusetts in the five years, 1907- r9r r, about 6,500 corporations were created ; and during the same period over 4,000 were dissolved .by the legislature. In 1911, it was reported

that 4,000 California corporations would be dissolved for failure to pay a license tax, and 4,000 more in Missouri for failure to file the annual anti-trust statement. This shows an extraordinary mortality among corporations in these states.•

In 1912, Express Real Estate Trusts in Boston alone owned $\$ 250,000,000$ of property and there had been no deaths among 17 of them in 14 years. ${ }^{5}$

In 1905, President SrMMOKS of the Fourth National Bank in New York, and of the New York Stock Exchange, said : "The exten- sion of the principle of incorporation has enabled leaders in business to set up two standards of morality, to maintain a Jekyll and Hyde duality, and to do as members of an impersonal and non-moral cor- porate body acts which they would shrink from as individuals. In private life they are stainless, but in the interests of corporations,

*** they will have recourse to every villainy damned in the decalogue." And in 1910, President IVILSON, in his address be-

fore the American Bar Association pleaded "earnestly for the individualization of responsibility within the corporation, for the establishment of the principle of law that a man has no more right to do wrong as a member of a corporation than as an inclividua 1." 7

On the other hand to quote !viaitla::-.'D, "It is said-and appeal is made to long experience,-that men are more conscientious w_hen they are doing acts in their own names than when they are using the

name of a corporation." 8 "A very high degree not only of honesty, but of diligence has been required of t rustees." 9 "No higher standards of administrative conduct are evoked by Courts than those which trusts require." 10

\section{Special Advantages of Corporations.}

The advantages of incorporation have long been recognized and frequently referred to in the literature of our law. More than six hundred years ago, BR $1 \backslash \mathrm{C} 1$ ' $0 \mathrm{~N}$ said: "If an abbot, $\quad$ or prior ***

- Chandler, Express Trusts, p. 10, and Supplement.

${ }^{1}$ Report of Tax Commissioner (Wm. D. T. Trefry), Mass. 1912, p. 18. Chandler, Express Trusts, p. $\|$

0 As quoted by Chandler, Express Trusts, p. .:zo, from the New York Daily Tribune, Oct. 7, 1905

7 The Lawyer and the Community, Am. Bar Assn. Rep., 1910, pp. .419, 438.

8 Maitland, Trust \& Corporation, Collected Papers, Vol. III, p. 362.

1 lb., p. 35.:z. -

• Chandler Express Trusts, p. 24. 
claim land in the name of their church upon the seisin of their predecessors $* * *$ the declaration should not be frorn abbot to abbot, or prior to prior, nor should there be mention of the intermediate abbots or priors, because in colleges and in chapters the same corporation always remains, although they all die successively and others are substituted in their place, as may be said of flocks of sheep, where there is always the same flock, although all the sheep or heads successively depart, nor does any individual of them succeed to another by right of succession in such manner that the right desce ds by inheritance from one to another, because the right always pertains to the church, and remains with the church. ** * And accordingly if the abbot or the prior, the monks or canons successively die, the house remains to etem ity."11

BLACKSTONE writing five centuries later than BRACTON, and at the very beginning of the application of science and invention to industrial conditions, in anything like modem ways, says in summing up the corporation law of his time:-

"To show the advantages of these incorporations, let us consider the case of a college in either of our universities, founded ad stu-dendum et orandum, for the encouragement and support of relig-ion and learning. If this were a mere voluntary assembly, the individuals which compose it might indeed read, pray, study, and perform scholastic exercises together, so long as they could agree to do so; but they neither frame, nor receive any laws or rules of of their conduct; none at least which would have any binding force, for want of coercive power to create a sufficient obligation. Keither

could they be capable of retaining any privileges or immunities ; for, if such privileges be attacked, which of all this unconnected

assembly has the right, or ability, to defend them? And, when they are dispersed by death or otherwise, how shall they transfer these advantages to another set of students, equally unconnected

as themselves? So, also, with regard to holding estates or other property, if land be granted for the purposes of religion or learning to twenty individuals not incorporated, there is no leg; al way of continuing the property to any other persons for the same purposes, but by endless conveyances from one to the other, as often as the hands are changed. But when they are consolidated and united into a corporation, they and their successors are then considered as one person in law; as one person, they have one will, which is collected from the sense of the majority of the individuals; this one will may establish rules and orders for the regulations of the whole, which

\footnotetext{
${ }^{11}$ Bracton, Treatise on Laws of England, (c. 1264), Vol. 5, Twiss's Ed., pp. 447-449.
} 
are a sort of municipal laws of this little republic; or rules and statutes may be prescribed to it at its creation, which are then in the place of natural laws; the privileges and immunities, the estates and possessions, of the corporation, when once vested in them, will be forever vested, without any new conveyance to new successions; for all the individual members that have existed- from the foundation to the present time, or that shall ever hereafter exist, are but one person

in law, a person that never dies; in like manner as the river Thames is still the same river, though the parts which compose it are chang- ing every instan t." 12

In 1819 Chief Justice MARSHAL!, put it this way: "A corporation is an artificial being, invisible, intangible, _and existing Qnly in contemplation of law. Being the mere creature of law, it possesses only those properties which the charter of its creation confers upon it, either expressly or as incidental to its very existence. These are

such as are supposed best calculated to effect the object for which

it was created. Among the most important are immortality, and, if the expression may be allowed, individuality: properties by which a perpetual succession of many persons are considered as the same,

and may act as a single, individual. They enable a corporation to

manage its own affairs and to hold property without the perplexing intricacies, the hazardous and enpless necessity of perpetual conveyances for the purpose of transmitting it from hand to hand. It is chiefly for the purpose of clothing the bodies of men in succession with those qualities and capacities that corporations were invented and are in use. By these means a perpetual succession of individuals are capable of acting for the promotion of the particular object, like one immortal heing." 1 ;

\section{Special Advantages of Express Trusts.}

Upon the other hand the special advantages of Express Trusts have recently been stated as follows :a

(I) These associations have been found by the experience of twentyfive years to be a convenient, safe and unobjectionable meth- od of cooperative ownership and management.

(2) The form of organization ensures a continuity of manage- ment and control which appeals strongly to investors in real estate. which cannot be secured by a corporation with changing officers. The trustees who are the managing officers of a trust are not so likely to be changed as are the directors of a corporation.

12 Blackstone, Commentaries, (1765), Ch. 18, Of Corporations.

u Trustees of Dartmouth College v; Woodward, (1819), 4 Wheat. (17 U. S.) 518

"Report of Tax Commissioner of Mass., 1912, p. 21. 
(3) It affords a more economical and more convenient and flexible form of management than does a corporation. Trustees can transact business with more ease and rapidity than directors.

"In the early development of uses a device was struck upon that

gave permanence as well as relief from the various feudal burdens. This was the joint tenancy. An owner will convey his land to a party of friends, to hold as joint tenants. "There will then be no inheritance, and no relief, wardship, marriage. By keeping up the wall of joint tenants, by feoffment and refeoffment, he can keep

out the lord and can reduce the chances of reliefs and so forth to nothing." 15 There is here no inheritance, only accrescence.

fr. :vL,1TLAND names "a few typical instances of unincorporated

bodies" that have lived behind the trustee wall for long periods of years." He says "Imagine a foreign tourist, with Baedeker in hand visiting one of our 'Inns of Court,' let us say Lincoln's Inn. He sees the chapel and the ,library and the dining hall; he sees the external gates that are shut at night. ${ }^{* * *}$ On inquiring he hears of an ancient constitution that had taken shape before $1422 . * * *$ You have here a Privateverein which has not even juristic personality. *** Its members might divide the property that is held for them by trustees. ** The English judges who received and repeated a

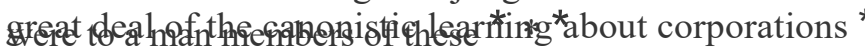

the want of juristic personality was a serious misfortune.17

and had never found that

Then there are (or were until 6 weeks ago) the ships of Com- merce carrying the name of Lloyds into all the seas of the world; almost from the beginning there was among these insurers of the world's commerce only a very loose organization with the exclusive use of a coffee house, and a .small trust fund, until the trust deed of 1811 was executed with over 1,100 signatures, and until 1871 "it was an unincorporated $V$ erein, without the least trace (at least so we said) of juristic personality about it." It was incorporated in 1871, because in that year there was recovered from the Zuyder-Zee, a large mass of treasure that had been lying there since 1799, and, because of the destruction of records by fire, it belonged to no one could say whom. ${ }^{18}$

There is also the London Stock Exchange, beginning in 1773 when the name was "wrote over the door" at New Johnathan's Coffee House. "In 1802 a costly site was bought, a costly building erected,

"Maitland, Lectures on Equity, p. 26

10 Maitland, Trust \& Corporation, Collected Papers, Vol. III, p. 336

${ }^{17}$ Maitland, Trust \& Corporation, Collected Papers, Vol. III, p. 369-371.

" lb. pp. 371-3:73 
and an elaborate constitution was formulated in "a deed of settlement." There was a capital of $£ 20,000$ divided into 400 shares. Be- hind the trustees stood a body of "proprietors," who had found the money ; and behind the "proprietors" stood a much larger body of "members" whose subscriptions formed the income that was divided among the "proprietors." "In 1876 there was a new deed of settlement; in 1882 large changes were made in it: there was a capital of $£ 240,000$ divided into 20,000 shares. $* * *$ The organization is of a high type. *** In 1877 a Royal Commission *** recommended that the Stock Exchange should be incorporated," and the bye laws be made sn!:>ject to the approval of the Board of Trade. "That; was the Cloven hoof. Ex pede diabolum." It was not incorporated, yet MAITLAND says; "it would not, I think, be easy to find anything that a corporation could do that is not being done by this nicht rechtsf iilzige V erein" ( society without legal capacity).$^{10}$ The New York Stock Exchange also is unincorporated.

MAITLAND, with his delightful humor, says again: "I believe that in the eyes of a large number of my fellow countrymen, the most important and august tribunal in England is not the House of

Lords but the Jockey Club. *** Some gentlemen form a club, buy a race course, the famous Newmarket Heath, which is conveyed to trustees for them, and then they can say who shall and who shall not be admitted to it. I fancy, however, that some men who have been excluded from this sacred heath ("warned off New .Market Heath" is our phrase), would have much preferred the major excommunication of that "historic organism" the Church of Rome." 20

This reference to the Church justifies further quotation from MAITLAND. He says "All that we English people mean by "religious \#btrty" has been intimately connected with the making of trusts. If in 1688 the choice had lain between conceding no toleration at all and forming corporations of Nonconformists," they would have been "Untolerated for a long time to come, for in Eng- land, as elsewhere, incorporation meant privilege and exceptional favour. And, on the other- hand, there were among the Noncon- formists many who would have thought that even toleration was dearly purchased if their religious affairs were subjected to State control. ${ }^{* *}$ If the State could be persuaded ${ }_{*} * *$ to repeal a few persecuting laws $* * *$ Trust would do the rest ***. Trust soon did the rest. ${ }^{*}$ And now we have in England Jewish Synagogues and Catholic cathedrals and the churches and chapels of

"Ib. pp. 373-376.

""Ib. p. 376. 
countless sects. They are owned by natural persons. They are owned by trustees." 21

In this way were the lands of the Methodist churches and chapels held throughout England and the United States, under model deeds used by John Wesley in the very beginninJ; of his ministry to the effect that the trustees, for the time being should permit Wesley himself, and such other persons as he might, from time to time ap- point, to have the free use of such premises, to preach therein God's holy word, and after his death "for the sole use of such persons as might be appointed by the yearly conference ;"22 these deeds were confirmed and made perpetual under his deed of trust of 1784, es- tablishing the :Methodist General Conference of 100 , and which has been called the Magna Charta of that church..$^{23}$

And although our Supreme Court has recently held, following the Supreme Court of the Philippine Islands, that the Roman Cath- olic Church is a corporation "which antedates by almost a thousand years any other personality in Europe," ${ }^{24}$ yet the great "organized operative institution" known as the Established Church of England, tracing its existence back to Theodore of Tarsus, 669 A. D. "is not a corporate body." •

It would seem from these illustrations, that other institutions known to the law based upon trusteeships rival in duration and permanence the immortality of corporations.

It is my purpose to compare these two,-Corporations and Express Trusts,-in such detail as my time will permit, to discover, if perchance we may, something of the strength and weakness of

for business purposes, under present day conditions. each,

\section{Theory of Corporate Existence. ${ }^{26}$}

A recent definition by Chief Justice BALDwIN of the Connecticut Supreme Court, says a corporation is "an association of persons to whom the sovereign has offered a franchise to become an artificial,

\footnotetext{
${ }^{21}$ lb. pp. 363-364.

${ }^{22}$ Life and Times of John Wesley. by L. Tyerman, Vol. 3, p. 419; Lost Chapters from Early History of American Methodism, by J. B. Wakeley, p. 58, where a copy of

the deed for a Methodist Preaching-house, on John Street, N. Y., dated Nov. 2, 1770, is given.

23 Tyerman, p. 421.

"Barlin ,.. Ramirez (1906), 7 Phil. 41; Ponce v. Roman Catholic Church (1908), 210 U. S. 296; Santos v. Roman Catholic Church (1909), 212 U. S. 463. ,. 3 Encyc. of Laws of England, p. 14; 2 Stephen's Commentaries, 16th Ed. (1914), p. 806; 1i" Halsbury's The Laws of England, p. 371, Sec. 706 (Ecclesiastical Law). "' Bibliography:

Angell and Amee, Law of Private Corporations, Introduction and Ch. I. (1st Ed. $183 r$, and subsequent editions.)

Baldwin, S. ,E., History of the Law of Private Corporations in the Colonies and
} 
States, Yale Bicen. Pub. 1901, p. 261, 3 Select Essays, Anglo-Am. Legal Hist., p. 236; Freedom of Incorporation, (in Modern Political Institutions, 1898).

Blackstone, Sir Wm., Commentaries (1765), Bk. I, Ch. xviii.

Brissaud, J., History of French Private Law, Continental Legal History Series,

(1912), pp. 889-905.

Brown, W. Jethro, The Austioian Theory of Law, (1906), pp. 254-270; The Per•

sonality of the Corporation and the State, 21 Law Quart. Rev. 365.

Carr, Cecil Thomas, Early Forms of Corporateness. Ch. IX, in General Principles of the Law of Corporations, 3 Select Essays, Anglo-Am. Legal Hist. (1905), p. 161; Select Charters of Trading Companies, 1530-1707. Selden Society, Vol. 28 (1913).

Cawston and Keane, The Early Chartered Companies, 1296-1858, (1896).

Clark and Marshall, Private Corporations, Vol. I, Ch. I.

Davis, John P., Corporations, A Study of Origin and Development, (1905); Nature

of Corporations, 12 Polit. Science Quar. 273.

Deiser, George F., The Juristic Person, 57 Am. Law Reg. (0. S.) 131, (1908).

Elliot, C. B., Private Corporations, Ch. I, (1897).

Evans, F., The Evolution of the English Joint Stock Trading Company, 8 Colum-

bia L. R. 339, 461 (1908); What is a company? 26 Law Quart. Rev. 259-263.

Freund, E., Legal Nature of Corporations, University of Chicago Studies in Polit.

ical Science.

Geldart, W. M., Legal Personality, 27 Law Quart. Rev., 90 -(1910).

Gierke, 0., Political Theories of Middle Ages, tr. by F. W. M.aitland (1913), In-

troduction pp. viii-xliii, 67-73, with notes.

Holdsworth, W. S., History of English Law, Vol. 3, pp. 362-376.

Johnson, A. B., Legislative History of Corporations in New York, 20 Hunt's Merchant's Magazine, 610 (1850).

Kent, James, Commentaries, (1827), Vol. II, Leet. 33.

Kyd, S., Corporations (1793), Introduction.

Machen, A. W. Jr., Corporate Personality, 24 Harv. Law Rev., (19n), pp. 253, 347.

Maitland, F. W, The Crown as Corporation, 3 Coll. Pap. pp. 244-270; The Unincorporated Body, lb., pp. 271-284; The Body Politic, lb., pp. 285-303; Moral Person- ality and Legal Personality, lb., pp. 304-320; Trust and Corporation, 1b., pp. 321-404.

See also 14 Journal Comp. Leg., p. 192.

Manson E., Evolution of the Private Company, 26 Law Quart. Rev., pp. 11-16.

Merritt, W. W., Some Views of the Nature and Effect of Corporateness, 10 Mich.

Law Rev., p. 310 (1912).

Miraglia, Luigi, Comparative Legal Philosophy, (Vol. III, Modern Legal Philos•

ophy Series, tr. by John Lisle, 1912), Ch. III, Incorporeal Persons, pp. 361-381.

Moore, J. H., Development of Corporation Law in this Country, Ark. Bar Assn.

Rep. (1909), pp. 45-81.

Morawetz, V., Private Corporations, Preface, 2d Ed. (1886).

Pike, L. O., Introduction to Year Book, 16 Ed. III, part I, p.xlvi.

Pollock, Sir F., Contracts, 6th Ed., 108; 7th Ed., 113; Has the Common Law Re-

ceived the Fiction Theory of Corporations? 27 Law Quart. Rev. ;119 (19n).

Pollock and Maitland, History of English Law, pp. 469-51I, 660-688.

Radin, Max, Legislation of Greeks \& Romans on Corporations (1909).

Rashdall, H., The Universities and the Legislature, 29 Law Quart. Rev., 76-84 (1913).

Raymond, R. L., The Genesis of a Corporation, 19 Harv. Law Rev. 350 (1906).

Salmond, J. W., Jurisprudence, Ch. XV, (3d Ed. 1910).

Scott, W. R., Constitution and Finance of English \& Irish Joint Stock Companies

to 1720,3 Vols. (1910-1912).

Seymour, E. B., History of the Common Law Conception of a Corporation, $42.1 \backslash \mathrm{m}$.

L. Reg. (N. S.), 1902, p. 529.

Sheppard, Wm., Corporations, Fraternities, and Guilds (1659).

Smith, H. A., The Persons Ficta, 26 Jurid. Rev., pp. 59-74 (1914).

Sohm, R., 'The Institutes of the Roman Law, Ledlie's trans., 2d Ed. (1901), Ch. II,

pp. 195-214.

State Trials, (King v. City of London), Vol. 8, pp. 1039-1358 (1682). 
juridical person, with a name of its own, under which they can act and contract, and sue and be sued, and who have accepted the offer and effected an organization in substantial conformity with its terms." 7

There are three fundamental ideas here: A corporation is a new person in the law resulting from the acceptance of a franchise to become such, by an association of persons.

The first of these,-that a corporation is a person, ${ }^{28}$ separate from its members, has already been referred ti'> as its chief characteristic and advantage. This idea of the personality and unity of a group is not new but old, almost as old as language. We are told nowa- days that the primitive mind of man had a more definite and positive idea of the unity and solidarity of the horde, or pack, or clan or tribe of savage hunters and warriors, than it had of the personality

of its individual members. ${ }^{29}$

Among all the Aryan peoples,-Hindu, Greek, Roman, Teuton, or Slav,-the oldest artificial person seems to have been the fam-ily.30 The Ancient Egyptians and Babylonians personified the Tem- ple.31 Long before JusTINIAN all the members of a corporation were considered one person or body in the Roman Law. ${ }^{32}$

The canonists of the 13th century call it a persona ficta, not found in the world of sense, but created by law, invisible, immortal, a body that has no body and no soul; it cannot sin, or be excom-

\footnotetext{
Sutton's Hospital Case, 10 Coke Rep,, pp. 1-35 (1613).

Taylor, H. O., Private Corporations, Prefaces, and Chs. I-IV. (1884 and subsc. quent editions).

Trapnell, Benj., The Logical Conception of a Corporation, West Virginia Bar Assn. Report 1896, Appendix to Clark on Corporations, 1st Ed., p. 643.

Trustees of Dartmouth College v. Woodward, 4 Wheat. (U. S.) 518.

Wilgus, H. L., Corporation Cases, pp. 1-167 with notes (1900).

IVilliston, Samuel, History of the Law of Business Corporations before 180o, 2 Harv, Law Rev., 105, 149 (1888), 3 Select Essays Anglo-Am. Legal Hist. p. 195. 496 ,

IVormser, I. M., Piercing the Veil of Corporate Entity (1912), 12 Col. Law Rev.

Wright, A. G., The California State Tax on Corporate Franchises, 1 Cal. Law Rev. 91, (1913),

Young, E. H., Legal Personality of a Foreign Corporation, 22 Law Quart. Rev.

178 (1906), Foreign Companies and Other Corporations, Cambridge University Press, 1912.

(The foregoing 'bibliography includes only such works as contain important matter relating to corporate theory or history.)

${ }^{21}$ Mackay v, N, Y., N. H. \& H. R. R. (1909), 82 Conn. 73, 81, 72 At!. 583.

${ }^{28} \mathrm{Sec}$ particularly in bibliography given in note 26 above, Blackstone, Brissaud, Brown, Carr, Deiser, Freund, Gcldart, Gierke, Machen, Maitland, Miraglia, Pike, Pol- lock, Salmond, SeymouT, Sohm, Wilgus.

${ }_{18}^{18}$ Morawetz, I 1, p. 2

10 Hearn, The Aryan Household, pp. 64-6.

n Johns, C. H. W., Babylonian \& Assyrian Laws, Contracts \& Letters, Ch. XX (1904); Simcox, E. J., Primitive Civilizations, Vol. I, pp. 171-179.

12 Amos, Sheldon, History and Principles of Civil Law of Rome, p. 118.
} 


$$
\text { - IO - }
$$

municated, nor commit a crime, and probably not a tort. ${ }^{33}$ Early in the 14th century these words were being repeated in the year books of English law by the English judges. In 1311 it was considered a body (im corps), existing per se, and not appendant or appurte- nant to something else. ${ }^{34}$ And only a short time ago : Ir. Justice McKENNA, of the United State Supreme Court said "Undoubtedly

a corporation is in law, a person or entity entirely distinct from its stockholders and officers." ${ }^{35}$ It is such, for the most part, in relation to outside parties; it has rights of property and reputation, and is subject to general duties under the common law and statutes; and is also considered a person as to ownership of property, and suing and being sued, and in considerable measure it is so under the protection of constitutional and treaty provisions. ${ }^{36}$

The second of these,-that a corporation results from the accept- ance of a franchis $e 3^{I}$ from the state,-although now so frequently criticized or belittled, historically has been as important as the personality of the corporation. In fact in legal theory, the privilege, the franchise itself, is the capacity of separate personality, conferred upon the group. The legal ideas involved come from the Roman and from the Feudal law. From the Roman, the franchise is a priv- ilege of a public nature conferred by the state for political or public reasons. Anciently perhaps in Greece and Rome groups of per- sons were associated without authority of the state, and acted much as a single person; but the Romans were jealous of such and many laws were made against illicit companies between the Twelve Tables (450 B. C.) and the Empire; Caesar and Augustus did the same; and in the time of Caius, and Marcian, corporations could be cre- ated only under special or general legislative authority. ${ }^{38}$

The same Political theory of corporate existence prevailed in the middle ages. "The corporation is and must be the creature of the

state. Into its nostrils the state must breathe the breath of fictitious life, for otherwise it would be no animated body but Individualistic dust." 39 In the Year Books of our law in 1376, it was ruled that

s, Pollock \& 1llaitland, Hist. Eng. Law, p. 477. Note 'Wilgus's Cases, pp. 72-79.

• Y. R., 4 Ed. II, 103; Y. B., 16 F,d. III; Pike's Introduction.

80 1\lcCask ill Co. v. U.S. (1910), 216 U.S. 504, 514. An,! Cave, J., In re Sheffield etc. Society (1889), says "A corporation is a legal person just as much as an individual." L. R. 22 Q. Il. D. 470 on 476.

""See Cases, IVilgus, Corp. Cases, pp, 33-72.

17 See bibliography in note 26 above, particularly, Blackstone, Gierke, (Maitland's tr. Introduc., pp. xx."ti-xxxviii), Kent, State Trials, Trustees Dart. Coll. , $\bullet$ IVoodward (Washington's Opinion), Wilgus, (Corp. Cases, pp. 113-170), Wright.

18 Kent, Comm., Vol. 2, pp. 268-9; Taylor's El. Civil Law, pp. 567-57r; Digest, xlvii, 22, 1 and 3 (Marcian); Digest, iii, 4, 1 (Caius).

•- Maitland's Summary, in Gierke's Pol. Th. of Mid. Ages, p. :o.xx. 
-'none but the king can make a corporation." ${ }^{40}$ And as we all know with us today "the right to form a private corporation can only be acquired from the state."n

From the Feudal law this privilege was not merely a personal privilege, but was looked upon as a privilege of a property kind. The :.Iedieval mind had a peculiar tendency to look upon all sorts of immaterial or incorporeal things and privileges as property; as for example, the right of adrnwson. Feudal rights and incidents, too intangible to be called holdings, were yet considered property in the :.Iedieval law."12 In 1691 it IVas said "the whole frame and essence of the corporation consist" of the franchises which are "the ligaments of this body politic." ${ }^{43}$ CoMYNS says in 1740, "A corporation is a franchise created by the king." BLACKSTONE and KENT say the same. Such a view is not dead nor sleepeth yet. It was the real basis of Mr. Justice WASHINGTON's decision in the Dartmouth Col- $l c g c$ case.u In 1887, Mr. Justice BRADLEY said: "A franchise is a

right of public concern. ${ }^{* *}$ No persons can make themselves a body corporate an.cl politic without legislative authority. Corporate capacity is a franchise."45 Ten years ago the Supreme Court of California said "The right to be and exist as a corporation is a

grant by the sovereign power, a valuable right" and subject to taxa-

tion.40 And just the other day it was said: "A corporate franchise is the right to exist as an entity for the purpose of doing things per- mitted by law." ${ }^{47}$ And the exercise of such right is subject to taxa- tion.48

The third of these,-that a corporation is really an association or collection of individuals, is strongly insisted upon by Mr. 1 forawetz and Mr. Taylor. Mr. Morawetz says: It is "essential to bear in mind distinctly that the rights and duties of an incorporated association,

are in reality, the rights and duties of the persons who compose it, not of an imaginary being." 40 And Mr. Taylor: There are "two

${ }^{\circ}$ Y. B., 49 Ed. III, 17.

n People v. Mackey (1912), 255 Ill. 144, 156, 99 N. E. 370.

., McKcchnie, Magna Carta, pp. 383-4.

"'King v. London, Carthew, 217; 1 Show. 275-6,

.. $4 \backslash$ Vheat. 518 on 657 , (1819).

• California v, Central Pacific Ry. Co., 127 U. S. „, 40.

.. Bank of California v. City \& Co. of San Francisco (1904), 142 Cal. 276, 100Am. St. R. 130, 75 Pac. 832; Crocker v. Scott, 149 Cal. 575, 87 Pac. 89; Western Union Oil Co v. Los Angeles (19n), 161Cal. 204, n8 Pac. 721; Farr Alpaca Co. v. Commw. (1912), 212 Mass. 156. Compare Detroit \&c. Ry. Co. v. Common Council (1901), 125

; \lich. 673, 84 Am. St. R. 589, 85 N. W. 96; Blackrock Copper Min. Co. v. Tingey (1908), 34 Utah 369, 98 Pac. 180; Cooper v. Utah Light \&c. Co. (1909), 35 Utah, 570, 102 Pac. 202. See 1 Cal. Law Rev. 91 (1913).

"State v. Business Men's Assn. ( 1914), - Mo. App., -, 163 S. W. 901.

•- People v. Sohmer (1914), 147 N. Y. S. 6II. p. IIO,

- Morawctz Private Corp. 2d Ed. Preface and U 227-231 ; Sec Note IVilgus Cases, 
meanings of the term corfX)ration; the one, the sum of legal rela- tions subsisting in respect to the corporate enterprise; the other the organic body of shareholders, whose acts cause the operation of the rules of law in the constitution. These two conceptions include all that is really connoted by the term in whatever sense used. And, if so, what has become of the venerable 'legal person'? Is he still somewhere, as he has aways been imagined? Or is he nowhere as he has always actually been? Shall we say he is the combination, the mystic unification of our two conceptions? Better not ; better forget him."Go

$$
\text { T/1<eory of the Tru.st. }{ }^{51}
$$

Trusts of course are the creation of the English courts of equity. As :IAITLAND says, "Of all the exploits of equity the largest and most important is the invention and development of the

"'Taylor, Private Corp., Preface, §§ 48-51. See Note \Vilgus Cases, p. $1_{\text {I }} 1$.

- 1 Bibliography:

- Ames, J. B., The Origin of Uses and Trusts, 21 Harv. Law Rev., 261-274 (1908),

${ }_{2}$ Select Essays Anglo-Am. Legal Hist. 737-752, Lectures on Legal History, pp. 233, 243. Cases on Trusts (1893).

Chandler, A. D., Express Trusts under Common Law (1912).

Cook, IV, W., Law of Private Corporations, 7th Ed., Vol. 2, § 622 (1913).

Cook, Prof. W. W., The Place of Equity in Our Legal System, Am. Bar. Ass'n

Rcpt. 1912, pp. 997-1009, 3 Am. L. S. Rev. 173.

Conyngton, Thomas, Corporate Organization, Ch. XLIII, pp. 362-374.

Fletcher, Charles, Essay on Estates of Trustees (1835).

Fonblanque, J., Treatise on Equity ( 1805), Book II, Chs. 1-8.

Gager, E. B., History of Equity in American Colonies and States, in two Centuries

of Growth of American Law, (Yale Univ. Studies, 1901 ).

Gilbert, G., Law of Uses and Trusts, (3d Ed. 1811 Sugden).

Hampson, Sir G. F., Liabilities of Trustees, and Indemnity allowed them by Courts of Equity (1830).

Hart, W. G., The place of trust in jurisprudence (1912), 28 Law Quart. Rev. 290.

Hill, James, Law Relating to Trustees (1846, and subsequent editions).

Hogg, J. E., Legal Estate in English Property Law (1910), 22 Jurid. Rev. 55-9.

Hohfeld, W. N., Relation between Equity and Law (1913), 11 Mich. Law Rev.

$537 \mathrm{ct}$ seq.

Holmes, 0. W. Jr., Early English Equity, , Law Quart. Rev. (1885), pp. 162-174,

2 Select Essays Anglo-Am. Leg. Hist. 705.

Jenks, Edward, The Legal Estate, 24 Law Quart. Rev. (1908), pp. 147-156.

Kerley, D. M., Historical Sketch of Equity Jurisdiction of Court of Chancery

(18go).

Kenneson, T. D., Cases on Trusts (19n).

Lewin, Thomas, Law of Trusts and Trustees (1839, and subsequent editions).

Loring, A. P., Trustees Handbook (3d Ed. 1907).

- Maitland, F. W., Equity (1910-13); Trust and Corporation, 3 Coll. Papers, 321-404. (1906)

Newbold, D. M., Notes on Introduction of Equity Juris. in Maryland 1634-1720

Page, T. N., Disappearance of fiduciary principle, 16 Am. Law Rev. 247, 302 (1908). Perry, J, W., Treatise on Law of Trusts and Trustees, (1872 and later editions). Pike, L. 0., Common Law and Conscience, 1 Law Quart. Rev. (1885), 443-454;

$\therefore$ Select Essays Anglo-Am, Leg. Hist., 722,

Pollock and Maitland, Hist. of Eng. Law, Vol. I, p. 520; Vol. II, pp. 228-239.

Robinson, C., History of High Court of Chancery, Vol. I (1882).

Sanders, F. W., Essay on Uses and Trusts (1791, and later editions). 
Trust. It is an institute of great elasticity and generality; as elastic, as general as contract." 62

Our trust is refined from the doctrine of uses as they were established in our law before the Statute of Uses. ${ }^{63}$ The older writers traced uses to the Roman fidei-commissa, introduced in the Roman law, 170 years B. C. to evade the laws prohibiting the appointing of a daughter, stranger or' an exile as an heir. The testator devised his property to a qualified citizen as his heir, uni- versal devisee, or executor, with a request, by precatory words, depending only on the good faith or honor, strong in the Roman breast, of such heir to restore or hand over the inheritance, or a part of it, to the designated person. To secure the enforcement of the request the testator implored or appealed to the Emperor, to AucusTus, who flattered by such appeal, on the advice of a committee of jurisconsults, made these requests obligatory, under the direction of the Consuls; and later under MARCUS AURELIUS, a praetor was appointed to enforce them, acting extra ordin em. ${ }^{34}$

Later writers, such as POLLOCK and MAITLAND, doubt the direct descent of our doctrine of uses and trust from this Roman origi- nal,55 mainly becaUje different terms were used in our early law. They say, however, that "The Frank of the Lex Salica, (475 A. D.)

Scrutton, T. S., Roman Law Influence in Chancery, 1 Select Essays Anglo-Am. Legal Hist., p. 208 ct seq.

, Sears, J. H., Trust Estates as Business Companies (1912).

Spence, George, Equitable Jurisdiction of the Court of Chancery (1846)

Tax Commissioner of Massachusetts, Report on Voluntary Ass'ns (1912); also Re- port of Special Commission to investigate voluntary associations in Massachusetts (1913). (No. 1788 House.)

Underhill, A., Law Relating to Private Trusts and Trustees (1896).

Veeder, V. V., A Century of English Judicature, 1 Select Essays Anglo-Am. Leg.

Hist., p. 730, 13 Green Bag, 23 ct seq.

Whitlock, A. N., Classification of the Law of Trusts, 1 Cal. Law Rev. 215 (1913).

Willoughby, R. M. P., The Legal Estate (1912), Cambridge Univ. Press.

Willis, J. W., Duties and Responsibilities of Trustees (1827).

Wilson, S. D., Courts of Chancery in the American Colonies, 28 Am. Law Rev. (1884), pp. 226-255, 2 Select Essays Anglo-Am. Leg. Hist. 779.

Woodruff, E. H., History of Chancery in Massachusetts, $S$ Law Quart. Rev. 370 (1889).

Of course much will be found in the standard works on Equity not mentioned above such as Abbott's Cases (1909), Adams (1850 and later editions), Beach (1892), Bispham (1878 and later editions), Eaton (1906), Hutchins and Bunker's Cases (1902), Langdcll (1904), Pomeroy (1881 and later editions), Smith, II. A. (1908), Snell, G. H. T. (13th

F.d. 1901 ), Story (1836 and later editions).

"'.Maitland, Lectures on Equity, p. 23.63

lb. p. 24.

"'Spence, Equitable Jurisdiction, Vol. I, p. *435, Kent, Com., Vol. 4, p. *289. Bernard's

First Year of Roman Law, U 813-818; Roby, Roman Private Law, Vol. I, p. 356.

II, p. 239

Maitland, Equity, p. 32; Pollock and Maitland, Hist. Eng. Law, 2d Ed., Vol. 
is already employing it; by the intermediation of a third person, whom he puts in seisin of his lands and goods, he succeeds in ap-pointing or adopting an heir." ${ }^{56}$ MAITLAND finds the same thing in the Lombard law. He says: "Th Lombard cannot make a genuine testament. He therefore transfers the whole or some part of his property to a Treiiliander, who is to carry out his instructions." , Mr. Justice HOLMES says that "The feoffee to uses of the early English law, corresponds point by point to the Salman of the early German law. ${ }^{* *}{ }^{*}$ The Salman, like the feoffee, was a person, to whom land was transferred in order that he might make a conveyance according to his grantor's directions,

usually after the grantor's death, the grantor reserving the use of

the land himself during his life. To meet the chance of the Sal- man's death before the time for the conveyance over, it was com- mon to employ more' than one, and persons of importance were selected for the office. The essence of the relation was the fiducia

or trust reposed in the fide/is nianus, who sometimes confirmed his

obligation by an oath or covenant. ${ }^{*} *$ The executor of the early German will was simply a Salman whose duty it was to see legacies and so forth paid if the heirs refused. ${ }^{*} *$ There can be no doubt of the identity of the continental executor and the officer of the same name described by GLANVILLE ( 180 ); and thus the connection between the English and the German law is made certain. ${ }^{58}$

"The beneficiary had however no action to compel the perfor- mance of the duty of the continental Salman," ${ }^{59}$ and "the transform- ation of the honorary obligation of the $\mathrm{f}$ eoffee into a legal obliga- tion was a purely English development."00 This duty was enforced against executors in the case of bequests of personal property, in the ecclesiastical courts, and possibly to some extent in the case of lands devisable by custom in some of the cities. ${ }^{61}$

For a long time even before the Conquest the term use had been in use, but yet as MAITLAND wittily says, it has "mistaken its own origin." The word is not the Latin "usus" (i. e. a using of a thing), but the Latin opus. From the 7th and 8th centuries, ad'opus, for "on his behalf," is found in Lombard and Frank documents;

\footnotetext{
- ${ }^{I}$ Trust and Corporations, 3 Coll. Papers, p. $327 \cdot$

. Holmes Early Eng. Equity, I Law Quart. Rev. 162-174 (1885); Select Essays Anglo-

Am. Leg. Hist., Vol. z, p. 705. Maitland, Equity, p. 26.

- Note 4, Ames, Lectures on Legal History, Origin of Uses, p. 237. 2 Select

Essays Anglo-Am. Leg. Hist., 737 et seq.

${ }^{00}$ Ames, Lectures on Legal Hist. p. 237.

${ }^{61}$ Ames, lb., p. 235; Holmes, Early Eng. Equity, 2 Select Essays Anglo-Am. Leg. Hist., pp. 710-714.
} 
in the Old French these become "al oes, ues," which the English tongue, confused with "use." The Latin records however read ad opus,-ad opus Johann is, i. e. on behalf of John. As far back as Domesday Book, one person is constantly doing things ad optts an- other; the Sheriff seizes "ad opus Regis, as os le Roy." 02 If one is going on a crusade he occasionally conveyed his land to another to be held to the use of his children, or his wife or sister, for he was not certain whether a woman could hold a military fee, or whether he could enfeoff his wife. So too, a man might want to give his property to a convent, to the use of the library, or the hospital. And when the Franciscan friars came as missionaries to the English towns, about 1225, with their rule forbidding them to own anything, the faithful benefactor, who wanted to give them some poor dormitory in which to live and sleep, struck upon the curious plan of conveying a house to the borough community "to the use of," or "as an inhabitation for" the friars. And by the time of BRACTON, "plots of land in London had been thus con- veyed to the city for the benefit of the F ranciscians." ${ }^{63}$ This was

in the 13th century.

In the 14th century, landowners began conveying lands to their friends a.d qpus suum, to the use of themselves. Why? Because they have found they can in effect make a will of their lands in

this way; for if A conveys his lanrl to B to hold on behalf of A while he lives, and then when A dies to give it to some one sug- gested by A before he dies, it is equivalent to a will. The direct devise of lands under the feudal system had been denied to land- owners for two or three centuries. Men especially among the great want to provide for their daughters and younger sons. John of Gaunt wants to provide for his illegitimate children. There were other reasons also; to avoid the feudal burdens of wardship, mar- riage, forfeitures and escheats, the statutes of mortmain,-and per- haps also to defraud one's creditors.e. Between 1396 and 1403, the Chancellor had interfered to protect these beneficiaries, and is ordering defendants by the writ of subpcena, "to do whatever shall be ordained by us," or to "do what right and good faith," or "good faith and conscience" demand, since the plaintiff "cannot have remedy by the law of the Holy church nor by the common law ;05 and one great doctrine, "Equity acts upon the person," was taking

a Maitland, Equity, p. 24. See Note, Pollock and Maitland, Hist. of Eng. Law, 2d Ed., Vol. II, p. 233.

- Pollock and Maitland, Hist. Eng. Law, Vol. 2, 2d Ed., p. 231.

"Maitland, Equity, pp. 25-30. p. 238 .

${ }_{11}$ Ames, Lectures on Legal History, Origin of Uses, Note 3, p. 236, and note 1, 
shape. "The law regards chiefly the right of the plaintiff and gives judgment that he recover the land, debt, or damages because they, are his. Equity lays stress upon the duty of the defendant, and decrees that. he do or refrain from doing a certain thing because he ought to act or forbear." 88

This term 'ad opus' in the early time was used also for what we now use "agency." In the very ancient days both in France and England, a man, such as the King's officer, will receive money not as agent of, but to the use of, ad opits, the king, or some one else; and in time, where the party is authorized to do some act in refer- ence to money or chattels on behalf of another, as where A's bail- iff, B, takes A's corn to market, sells it, and buys cattle, ad opus A, this develops into a law of agency, so that if B converts the corn or cattle or money received to his own use (ad opus suum proprium) the common law will recognize the wrong and furnish a remedy in debt or account. ${ }^{87}$

It was not so however in the case of land, although it looks much like a contract, and there certainly is an agreement when "in considef'ation of a conveyance made by A to X, Y, Z, they agree that they will hold the land for the behoof of A, will allow him to enjoy it, and will convey it as he shall direct." ${ }^{69}$ Why is this not a con-

tract, and why did the courts not enforce it? There are two or three reasons: (I) The feofee did not formally promise, or covenant under his seal; (2) In the 14th century the common law had not begun to enforce 'the simple contract,' and by the 15th century when the simple contract began to be enforced in the courts of common law," in an action of assumpsit, the Chancellor was already in possession of this field of jurisdiction and was already enforcing uses by means of a procedure far more efficient and far

more flexible than any which the old courts could have employed;

(3) Where the promise was to convey as directed after the death of the . feoffor, of course the feoffor could not enforce it, his heir would not, for it would be to his interest not to do so ; so the only one wanting to enforce it would be the beneficiary; the court of Chancery early recognized this, and gave him the remedy, and even in the earliest instances where the trustor and the cestui que use $e^{10}$ are the same, still it is as "destinatory," not as "author of the trust" that he has the remedy. This marks it off from contract.

(4) Then again if the feoffor who was also the cesttti qtte use, had

\footnotetext{
"'Ames lb., p. 231

${ }^{81}$ Pollock and Maitland, History of Eng. Law, 2d Ed., Vol. II, pp. 229, 230.

- lb., p. 231

${ }^{00}$ Maitland, Equity, p. 28

ro On the proper use of this term, and ccstui quc trust, see 26 Law Quart. Rev. 196.
} 
only a contract right, it would be a chose in action, and inalienable, which the landowner did not want. ${ }^{71}$

And so what kind of a right is this which the destinatory, th beneficiary, the cestui que use, has? Is it a right in rem or in personam? To follow MAITLAND here: "It seems a little of both."72 "The right of cestui que use or cestui que trust begins by being a right in personam. Gradually it begins to look somewhat like a right in rem. ${ }^{18}$ But it never has become this, no, not even in the present day." "The new class of rights is made to look as much like rights in rem (estates in land) as the Chancellor can make them look; that is in harmony with the real wish of the parties who are using the device. They are also taking the common law as their model. Thus we get a conversion of the use into an incorporeal thing,-in which estates and interests exist,-a sort of immaterial- ized piece of land." $\mathrm{H}$ "The use came to be conceived of as a sort of metaphysical entity in which there might be estates very similar to those which could be created in land, estates in possession, re-

mainder, reversion, estates descendible in this way or tha t." ${ }^{17}$ But it is "neither jus i1' re nor ad rem, neither right, title nor interest in law, but a species of property unknown to the common law, and owing its existence to the equitable jurisdiction of chancery, rest-

ing upon confidence in the person and privity of estate; $* * *$ it was rather a hold upon the conscience of the f eoffee to uses than a a lien upon, or interest in the land; and the principle upon which it was founded was that the feoffee was bound in conscience to fol- low the direction of the $f$ eoffor." 76

"The trustee is the owner, the full owner of the thing, while the cestui que trust has no rights in the thing." 77

This thing,-the trust res, or trust fund owned by the trustee the court of chancery converted into an incorporeal thing which can change its dress but maintain its identity. "Today it appears as a piece of land; tomorrow it may be some gold coins rn a purse;

n Maitland, Equity, pp. 28-31.

12 lb., p. 23.

13 lb., p. 29 .

.. lb., p. JI.

15 lb., p. 33.

"Stebbins, Senator, in McCartee v. Orphan's Asylum (1827), 9 Cowen (N. Y.) 437, 18 Am. Dec. 516, I Wilgus, Corp. Cas. 1021. Wehner v. Thurmond (1908), 17 Wyo. 268, 129 Am. St. R. 111 3, 98 Pac. 590, 99 Pac:. 1 128. On the nature of a trust, see particularly cases in Ames's Cases on Trusts, Secs. I to V, pp. 1-77, Ch. I; Secs. I and II, Ch. II, pp. 235-278. Hart, W. G., The place of trust in jurisprudence (1912), 28 Law Q. Rev. 290; Whitlock, A. N., Classification of the law of trusts \{1913), 1 Cal. Law Rev. pp. 215-221.

${ }^{11}$ Maitland, Equity, p. 47. Ames's Cases, Ch. II, Sec. II, pp. 235-278; Kenneson'a Cases, Ch. II, pp. 111-152. 
then it will be a sum of Consols; then it will be shares in a Rail- way Company; and then Peruvian Bonds. When all is going well, changes of investment may often be made; the trustees have been given power to make them. All along the 'trust $\mathrm{f} 11 \mathrm{nd}$ ' retains its identity. ${ }^{*} *$ But the same idea is applied even when all is not going well." 78

Mr. MAITLAND contends stoutly, and perhaps correctly, notwithstanding frequent loose statements to the contrary, that the bene- ficiary has no right in the thing, in the trust fund; the equitable

estates and interests are not jura in rem; * * but essentially jura in personam, not rights against the world at large but rights against certain persons. ${ }^{70}$ Notwithstanding this, the beneficiary is treated as having an estate in fee simple, or in fee tail, or for life in the use or trust, or an equitable estate ; or as having a term of years in the use or trust. These estates and interests were to devolve and be transmitted like the analogous estates and interests known to and protected by the common law. The equitable fee would descend to heirs general, the equitable estates tail to heirs in tail, equitable chattel interests would pass to the executors or administrators. $* * *$ The equitable estate or interest could be conveyed or assigned inter vivos; and they can be devised or bequeathed ; curtesy but not dower could be had in them ; they did not escheat; and they

could be reached by a creditor of the beneficiary.

All these look like rights in rem. Yet "the right of the cestui que trust is the benefit of an obligatioa, ${ }^{80}$ and is available against not the whole world, but only against certain persons; these are: (I) The trustee who has undertaken to hold in trust; (2) "those who come to the lands or goods by inheritance or succession from the original trustee, his heir, executors, administrators, or doweress;

(3) the trustees creditors; (4) the trustees donee, who takes without giving a valuable consideration; (S) the purchaser fr'om the trustee for value, who knows of the trust; (6) the purchaser from the trustee who ought to know of the trust," "who would have known of the trust had he behaved as prudent purchasers behave,"- according to the estimate of equity judges,-and not of an ordinary jury. If he did not come up to this standard he was "affected with notice," or had "constructive notice," and was not protected. ${ }^{81}$

"Ilut here a limit was reached. Against a person who acquires a legal right bona fide, for value, without notice express or con-

'"Maitland, Trust and Corporation, 3 Coll. Papers, pp. 350-351,

n Maitland, Equity, p. 112, et seq. Langdell, Equity, pp. 5-6, 254 (2d Ed.).

., lb., p. 116. But compare Mr. Whitlock's article in 1 Cal. Law Rev. 215, and Bispham'• and Pomeroy'• Classifications.

11 Maitland, Equity, pp. 117-119. 
structive of the existence of equitable rights those rights are of no avail,"-and here is the difference between the beneficiary's right, and a true right in rem. ${ }^{82}$

\section{Creation of Corporations.}

Long ago, Lord CoKE in the Case of Sutton's Hospital, said these "things are of the essence of a corporation: (I) Lawful authority of incorporation; and that may be by four means, sc. by the common law, as the King himself, etc.; by authority of parliament; by the King's Charter, (as in this case) ; and by prescription. The $2 \mathrm{~d}$ which is of the essence of the incorporation, are parties to be incorporated, and that in two manners, sc. persons natural, or bodies incorporate and political. (3) A name by which they are incor- porated, as in this case governors of the lands, etc. (4) Of a place, for without a place no incorporation can be made; here the place

is in the charter house in the County of Middlesex. * * * (5) By words sufficient in law, but not restrained to any certain legal and prescript form of words." 88

This statement, for the most part is as applicable and accurate today as it was three hundred years ago when it was written. We yet have corporations existing by the common law,-as the state itself is a corporation, and our governors and officers are corpora- tions sole for certain purposes, by implication or necessity. ${ }^{84}$ Public corporations may exist with us by prescription, and private also, where the statute of limitations runs against the state in quo war-

ranto proceedings.n We still have corporations in this country that exist by virtue of a King's charter granted before the revolution, as in the case of Dartmouth College ${ }^{86}$ This method of creating cor- porations de novo, still exists in England, but of course not with us; and although Lord BALTIMORE, under authority conferred upon him by the Charter of Maryland in. 1667 incorporated the Mayor, Re- corder, Aldermen and Common Council of the City of St. Marys, and William PENN, by a similar provision in the Charter of Penn- sylvania, in 1701 granted a charter of incorporation to the city of

\footnotetext{
621 b., p. 119. p. 264.

"'The Case of Sutton's Hospital (1613) 10 Coke 1, 23a et seq., 1 Wilgus Cases,

${ }^{81}$ The Governor v. Allen (1847), 8 Humph. (27 Tenn.) 176, 1 Wilgus, Corp. Cases, 70 , note 275 .

.., Greene v. Dennis (1826), 6 Conn. 292, 16 Am. Dec. 58, 1 Wilgus Cases, 275, note 78; State v. Pawtuxet Turnpike Co. (1867), 8 R. I. 521, 94 Am. Dec. 123; People v. Oakland Co. Bank, 1 Doug. (Mich.) 285.

"Trustees of Dartmouth College v. IVoodward (1819), 4 Wheat. (17 U. S.), 518, $1 \backslash$ Vilgus, Corp. Cas. 708.
} 
Philadelphia, ${ }^{87}$ no such power now exists with us in any executive or judicial office. And since the American revolution the power to create corporations, with us, has resided in our legislative bodies exclusively. 88 Such power, however, when in our legislatures, is qualified only by constitutional limitations. ${ }^{89}$ And in the absence of constitutional provision the legislature may act by special or general laws. General incorporation laws probably existed at Rome. ${ }^{00}$ In England the first general incorporation law was enacted by Parlia- ment in 1597 for the erection of hospitals; this was made perpetual in 1624; it is still in force, and Lord COKE, in his Second Institute gives the act and a proper form for incorporation under it. ${ }^{91}$ The political dogmas of the American and French revolutions, that all men are created equal, and are entitled to equal rights, issued in the demand for equal privileges in the formation of corporations.

To satisfy this demand and prevent the fraud and legislative job-

bery incident to the granting of the privileges of incorporation by special acts, it became the policy to incorporate under general laws.

As early as 1784, general laws were passed in New York for the incorporation of Churches; these were followed rapidly in other

states. In $\mathrm{r} 8 \mathrm{u}$, New York passed the first general incorporation law for incorporating manufacturing corporations. This was fol- lowed in Massachusetts in 1836; in Connecticut and Michigan in 1837; and by Indiana in $1838 .^{92}$

But passing general laws did not meet the whole difficulty, for the legislatures continued to create corporations under special acts. Constitutional limitations therefore became necessary. In 1821 New York required the assent of two-thirds of the members of both houses of its legislature.

In 1838 Florida by constitutional provision forbade the incorporation of churches by special act, and directed that a general law be enacted for their creation. In 1845 Louisiana did the same for all except municipal corporations. In 1846 New York did likewise;

\footnotetext{
sr Mc Kim v. Odom. 3 Bland Ch. (Md.) 407, 1 Wilgus Corp. Cas. 222; 1 Wilson's Works. (Andrews' Ed.), 561; Machen, Modern Law of Corporations, p. 3, note 3

Poorc's Charters Vol. 2, p. 1388, Par. 14 (North Carolina). note 286

""Franklin Bridge Co. v. Wood (1853), 14 Ga. So, I Wilgus, Corp. Cas. 279,

"'Bell v. Bank of Nashville (1823), Peck (7 Tenn.) 269; Penobscot Boom Corp. v. Lamson (1839), 16 Me. (4 Shep) 224, 33 Am. Dec. 656, $1 \backslash$ Vilgus, Corp. Cas. 283; 1 Hamilton's Works, iii; 1 Wilson's Works, 561; Luxton v. North River Bridge Co. (1894), 153 U. S.

oo Baldwin, Modern Political Institutions, Freedom of Incorporation. .139 Eliz. Ch. 5 (1597); 21 Jas. 1, Ch. 1, (1624); 2 Inst., p. 723; 6 Encyc. of Laws of England 233.

.. Note (b) 2 Kent's Com. p. [342]. Laws of New York 1784, 7 Secs., Ch. 18; Laws of N. Y., 18II, Ch. 67, 3 Secs. Notes I and 2, I Machen, Corp. p. 15.
} 525 . 
and now almost every state constitution provides that the legisla-

tures shall pass no special act creating corporations or conferring corporate powers, but all corporations shall be created under general laws which shall be subject to amendment and repeal by the legislature at any time. ${ }^{03}$ Mr. FROST says special charters can be granted in only seven state $\mathrm{s} .^{04}$

In speaking of the general incorporation laws, $J \backslash f r$. ILICHEN says, "The statutes in some states consist of a jumble of old acts thrown together almost indiscriminately with more recent amendments. In other states, the legisatures have intended to display the utmost lib- erality; but unfortunately this disposition has often been evinced by removing salutary restrictions and at the same time, in order to make a show of legislative regulation, by imposing vexatious and unreasoning restraints."

1r. FROST says that "a great majority of the business corporation acts in force in this country today are sadly in need of revision.

* * * The incorporation laws of Georgia, Pennsylvania, and Mary- land are veritable "legal antiques," * * * and the acts of many of

the states are "wonderfully and fearfully made." ${ }^{96}$ And every law- yer that has tried to find out the real meaning of the corporation statutes of a single state, knows that such mild expressions are alto-

gether too euphonious to do the subject justice.

Not only are incorporation laws notoriously uncertain in mean- ing, but they are inflexible so long as they last, and when, in what way, and to what extent, they will be changed by the legislature,

Providence only, if anyone, can tell.

Then again one must at his peril substantially comply with the

law whether he can determine its meaning or not; and in many states if he fails so to comply he can only say some sort of disaster will follow, exactly what under the present state of authorities, he

cannot tell, for it is concealed in gremio legis et curiae; in one place

it will be de facto existence $;{ }^{97}$ in another not $;{ }^{98}$ in one a full part- nership liability for members; in another an individual liability for participant $\mathrm{S},{ }^{100}$ - but for all, even though they acted in good faith, it will be something different from what they intended.

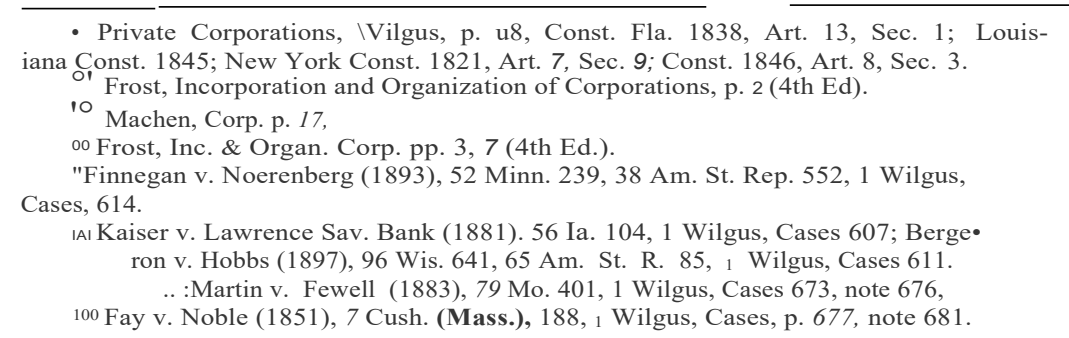


Then too it is difficult, if not impossible, unless the Supreme Court has passed upon it, to say what is the period of corporate gestation, when it begins or when it ends, when corporate birth really occurs, when corporate parturition is complete, when the um- bilical cord is cut, and the corporate "personality" is acquired. For example, where the statute reads that "articles of incorporation shall he executed stating name, purpose, place of business, term,

number of directors, names of those for first year, amount of cap-

ital stock, and number of shares, and shall be filed in the office of the secretary of state, and thereupon the signers shall be a corpora- tion," at least four different views are taken: (1) Corporate life for all purposes begins immediately on filing the articles, ipso facto eo i1 1 stal1 ti, without reference to any stock subscription or organiza- tion.101 (2) There is no corporate life until corpdrate r,rganization.

by election or appointment of officers. 102 (3) There is only aqualified corporate existence resulting from filing articles and adult cor- porate life only after the requisite stock is subscribed and paid in. 103

(4) Corporate life begins on the filing, but the incorporators whether subscribing for stock or not, are tenants in common of the proposed amount until it is duly subscribed by others. ${ }^{104}$

\section{Creation of E.rpress Trnsts.}

Upan the other hand the creation of an express trust is a matter of the mere declaration of the tmstor or declarant, accepted by the trustee, or of a contract between them. 105 There are no special statutes to comply with except the Statute of Frauds, the Statute of

Uses, statutes relating to Perpetuities, and to Conveyancing and Recording.

These will be considered in other connections. At this point it is only necessary to say that for !:he most part these are easily com- plied with. The Express Trust is a matter of a declaration of an owner or of an agreement between parties under their common law rights and can be moulded to suit the needs an-: wishes of the par-

ties, and it can be made as certain, definite and clear as the skill of the draftsman will permit in expressing the intentions $\mathrm{O}$ : the parties, 106-and it will at least not be defeated by incorrect gues!:es at the meaning of uncertain, if not inconsistent, provisions of written law. The balance here certainly is in favor of the trust.

\footnotetext{
${ }^{101}$ Singer Mfg. Co. v. Peck (1896), 9 S. Dak. 29, 67 N. W. 947, 1 Wilgus, Cases 571.

${ }^{102} \mathrm{~W}$ alton v. Oliver (1892), 49 Kans. 107, 33 Am. St. R. 355, 1 Wilgus, Cases, 565.

"'"Wechselberg v. Flour City National Bank (1894), 24 U. S. App. 308, 1 Wilgus, Cases, 574.

${ }^{101}$ Hawes v. Anglo-Saxon Petroleum Co. (1869), 101 Mass. 385, 1 Wilgus, Cases 581 too Maitland, Equity, pp. 53-56.

"'" lb., 57-70.
} 


\section{Steps in Creation of Corporations.}

Mr. FROST enumerates ${ }^{107}$ the various steps necessary to create a corporation under modern business corporation acts, as follows:

(I) The drafting of the articles of incorporation;

(2) The signing of the articles by the requisite number of incorporators, and the acknowledgement of the same before an officer $<$ luly authorized to take such acknowledgements;

(3) Filing and recording the articles with the proper state and county officials after payment of the requisite organization tax and filing and recording fees;

(4) Organization of the corporation ready for the transaction of busine,;s;

(5) Securing the necessary permit from state officials (if any is required), to transact business in the domiciliary state.

\section{Steps in Creation of Trust.}

On the other hand a recent case has said the requisites of a valid trust are: " (I) A designated beneficiary; (2) a designated trustee,

who must not be the beneficiary; (3) a fund or other property sufficiently designated or identified to enable title thereto to pass to the trustee; and (4) the actual delivery of the fund or other property, or of a legal assignment thereof to the trustee, with the intention of passing legal title thereto to him as trustee." 108

Let us consider these things a little more fully in reference to the creation of Corporations and of Trusts.

\section{The focorporation Paper.}

Under all general incorporation laws, some kind of a document must be executed in a particular way, and filed, deposited, or recorded, in a specific way. The name of this document is various,-"deed of settlement," "articles of association," "articles of incorporation," "articles," ';certificate of incorporation," "charter," "memorandum of association,"-all of which Mr. 1 lfocmm considers objectionable, and suggests that "incorporation paper" be used, although as he says, that "term does not seem to have been used in any state or country." 100 It seems however that it is not fatal to call it Articles of Association when it ought to be called " Charter." 110

IDT Frost, Inc. and Org. Corp., p. 12 (4th Ed.).

100 Brown v. Spohr, 180 N. Y. 201, 209, 73 N. E. 14, 16; Central Trust Co. v. Gaffney, 142 N. Y. S. 902, 905, 157 App. D. 501. Kemmerer v. Kemmerer (1908), 233 Ill 327, 122 Am. St. R. 169, 84 N. E. 256; Ranney v. Byers (1908), 219 Pa. 332, 123 Am. St. R. 66o, 68 Atl. 971.

${ }^{100}$ Machen, Corporations, p. 30, I 32.

110 Kaiser v. Lawrence Sav. Bk. (1881), 56 Ia. 104, 1 Wilgus, Cases 6o7, on 6 o8. 
In any event there must be a written or printed incorporation paper.m The drafting of this document, under printed forms, that are usually furnished upon application seems to be a simple matter, and is often done without much professional consider:ition. How- ever since the document, will constitute, together with the law under which it is executed, a contract of a dual nature,-one between the

corporation and the state, and another among the shareholders themselves, 11 to be construed "rig-idly in favor of the public and against the corporation ;"113 and since the express powers of a corporation are such as are found expressed in the statute under which the cor- poration is to be forn 1 ed, or such, as though not so expressed, may be lawfully claimed, if specified in the incorporation paper. though not otherwise, much skill is required to get the best results.rn Mr. FROST enumerates 28 different classes of express pOlvers, 21 of which are expressed in most general laws, but 7 of which if desired. must

usually be claimed in the incorporation paper, if they can be had at all ;m and, although formerly it was held that one state could not spawn its corporate progeny to do business in another state, yet that view has been abandoned so completely that the states have become unseemly competitors in vending their corporate wares, to such an extent that every important business seeking incorporation asks where can the incorporation be had with a maximum of power, and a minimum of inconvenience; so where to incorporate has become a question of extreme importance, and can be answered only par- tially by any lawyer after careful investigation and comparison of statutes. Mr. FROST suggests 21 ciuestions to be answered in this connection, and these certainly do not cover more than half the ground; all these considerations make it certain that the proper drafting of important incorporation papers requires a high degree of skill and experience. $\mathrm{U}^{6}$

The incorporation paper must be executed as the statute provides, and there are many pitfalls here also. If the statute sa 's that "any number" may form a corporation, by signing articles of association, and stating, among other things, the "names and residence" of the signers. and there are 27 signers, but only two state their residences, the corporation in Indiana, at least, is not de jure; $\mathrm{m}$ so too if the

\footnotetext{
= Utley v. Union Tool Co. (1858), 11 Gray (Mass.), 139, 1 Wilgus, Cases, 597.

112 ilachen, Corporations, pp. 32-33; Wilgus, Corp. Cases, p. 707 et seq.

uj Oregon Ry. Co. v. Oregonian Co. (1888), 130 U. S. 1, 1 Wilgus, Cases, p. 429.

114 Machen, Corporations, H 48-63, 64-102.

${ }^{110}$ Frost, Inc. \& Org. of Corporations, 4th Ed., U 17, 18, pp. 34-36.

11 lb. I 18, p. 35 . Wilgus, Corporations, I 49.

m Busenback v. Attica \&c. Road Co. (1873), 43 Ind. 265, 1 Wilgus, Cases, p. 600.
} 
residence of directors is omitted when the statute requires it; so where the "principal place of business" is to be stated, it won't do to say "the operations of the company are to be carried on"11 8 in a certain county; and in :Maryland it seems that even a church, though it has been running as an incorporated body for years, taking a deed for its property, giving a mortgage upon it, issuing bonds, etc., cannot be held liable for its just debts, if its articles were acknowledged

before only one justice of the peace, when two were required. ${ }^{110}$ And in $\backslash \mathrm{Vi}$ consin, where the statute requires the certificate of organiza- tion to be filed with the register of deeds,-and where the original certificate of organization was left with the recorder, long enough to be recorded in his office, and was so recorded by copying in the record books, and was then returned to the supposed corporation,

instead of being left on file in the recorder's office, there was neither a corporation de jzire nor de facto. ${ }^{10}$

Then too the incorporation fee, varying from a few dollars in some states to a large sum in others must be paid, or there is, at least, in Colorado, neither a corporation de j11re, de facto nor by esto ppel. ${ }^{121}$ In Arizona it would have cost $\$ 45$ to incorporate the United States Steel Corporation; it cost $\$ 220,000$ in New Jersey; and it would have cost in Pennsylvania, $\$ 3,666,666 .{ }^{122}$

I have already spoken sufficiently of the variety of view, and conflict of authority as to when the corporate organization is complete. and real corporate birth occurs. Under the statutes of many states certain things must be done before the corporation can "commence business," and there has 1;ieen much difficulty to determine the result of a failure to do all these things. Perhaps it is reasonably safe to say that if the duty to do these things before commencing business is placed by the statute upon those seeking incorporation, such will be a mandatory condition precedent to valid corporate existence : whereas if the duty seems to be rather upon the corporation, instead of those seeking incorporation, it will be a condition subsequent; but in either case the state can bring quo warranto, in the one case against the unsuccessful incorporators, in the other against the de- faulting corporation, disaster being possible in either case. ${ }^{123}$

ua Harris \& Stickle v. McGregor (1865), 29 Cal. 124, 1 Wilgus, Cases, p. 603.

m Boyce v. Trustees \&c. (1876), 46 Md. 359, 1 Wilgus, Cases, p. 642.

:uo Bergeron v. Hobbs (1897), 96 Wis. 641, 65 Am. St. R. 85, 1 Wilgus, Cases, 611.

121 Jones v. Aspen Hardware Co. (1895), 21 Colo. 263, 52 Am. St. R. 220, I Wilgus,

Cases, 637

122 Frost, Inc. \& Org. Corp,, 4th Ed., Table iii.

uo Mokelumne Hill Mining Co. v. Woodbury (1859), 14 Cal. 424, 73 Am. Dec. 658,

1 Wilgus, Cases 296; Harrod v. Hamer, (1873), 32 Wis. 162, 1 Wilgus, Cases, 586. 


\section{Trust Instrument.}

Now let tts see how it stands with an Express Trust. MaITLAnd says: "In the old days no deed, no writing was necessary to create a use, trust or confidence. I enfeoff you, and by word of mouth I declare that you are to hold to the use of X. You must hold to the

use of X. As to trusts this still is law, except in so far as it has been altered by the Statute of F rauds." 124

The Statute of Frauds of 1677, provided (§ 7) that "All declarations of or creations of trusts or confidences of any lands, tenements or hereditaments shall be manifested and proved by some writing signed by the party who is by law enabled to declare such trust, or by his last will in writing, or else they shall be utterly void and of no effect," but by section 8 , this was not to apply where the trust results "by the implication or construction of law." 12

It is to be noted here that this statute applies only to real property, aud not personal property ; $;^{126}$ that writing only, not a deed, no sealed instrument, no witness, no acknowledgement is necessary; and fur- ther no writing is necessary to create the trust, but only to manifest and prove it "The statute will be satisfied if the trust can be manifested and proved by any subsequent acknowledgement by the trustee, as by an express declaration by him or by a memorandum to that effect, or by a letter under his hand, or by a recital in a deed exe- cuted by him ; and the trust, however late the proof, operates retro- spectively from the time of its creation."121 But Courts of Equity went further and held "the Statute of Frauds does not prevent the proof of fraud," and "it is a fraud for a person who knows land has been conveyed to him in trust, to deny the trust and claim the land himself." 128

In a few states this section of the Statute of Frauds is not in force, and in a few, a deed instead of merely a writing is required, but in

most states the statute is in force with the effect above given. ${ }^{129}$

As noted it does not apply to personal property, nor does it require a contract or consideration to make one a trustee. ${ }^{130}$

The 9th section of this statute however required that every grant or assignment of a trust, that is the beneficial interest, "be in writing,"

12' Maitland, Equity, p. 57.

'"' 29 Chas. II, c. 3. Maitland's Equity, p. 57; Ranney v. Byers, (1908), 219 Pa.

332, 123 Am. St. R. 660, 68 Atl. 971; Ames, Cases, I 8, pp. 176-189.

10 Maitland, Equity, pp. 58-59.

m Lewin, Trusts, 11 th Ed., p. 56; Maitland, Equity, p. 58.

${ }^{121}$ Maitland, Equity, 59; Rochefoucauld v. Bonstead, (1897), 1 Ch. 196

121 Cook, Trusts \& Tusttees, I 53; Ames, Cases, pp, 176-177.

130 Maitland, Equity, p. 53; Cook, Trusts \& Trustees, \$I 45-47. 
an $<1$ not merely manifested or proved by a w riting. ${ }^{131}$ So too the I 3th Elizabeth forbidding all conveyances to delay, hinder or de- fraud, creditors: and the 2ith Elizabeth forbidding voluntary con- veyances to defraud and deceive subsequent purchasers, of course, apply to conveyances in trnst as well as to other conveyances. These :i.re generally in force in this country $-13^{2}$

To quote M,ITLIND again: "The creation of a trust may be a perfectly unilateral act, there may not be more than one party to it. $\therefore{ }^{*}$ " I declare myself a trustee of this watch for my son who is in

India. If I afterwards sell that watch, although my son has never

heard of the benefit that I had intended for him, I commit a breach of trust and my son has an equitable cause of action against me." 133

While it is usually said that "no one can be compelled to undertake

a trust," yet because courts of Equity have been so jealous of its pet, LITLAND points out "In practice it would not be very sage to rely upon this doctrine, for one may very easily do something or say something that can be regarded as an acceptance of the trust" with all its attendant duties, that cannot be easily got rid of. "There-

fore if you hear that anyone has been conveying property toyou as a trustee, and you do not wish to be burdened with a trustee's duties, you will be wise in repudiating in some emphatic manner the rights

and the duties which were to have been thrust upon you." 134

Ko specific words are necessary. "The words 'use' and 'trust' are not sacramental terms." In fact "the most untechnical words," mere precatory words, such as "desire," "will," "request," "entreat," "beseech," "recommend," "hope," "do not doubt," have been held sufficient in wills; all that is required is a reasonably clear expression

of the decla rant. ${ }^{135}$

The Statute of Uses, 27 _Henry VIII, 1535, provided that the legal estate should follow the use, so that the beneficiary should thereafter become the legal owner. It read that wherever one person "was seized of land to the use of another," in fee simple, or fee tail, or for life, or for vears, the latter shall be deemed to be in lawful, seizin, estate, an 1 possession, of such land in such like estate as he had in the use. ${ }^{10}$ It is to be noted (I) The Statute does not apply to chattels personal. (2) Nor does it apply to leaseholds for years, that is where the estate in the tmstee is for years, since seizin applied

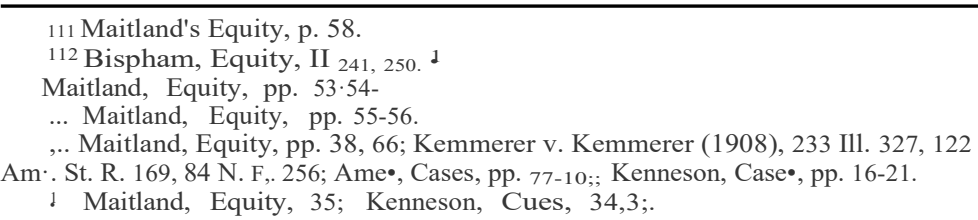


only to freeholds; but on the other hand if land is conveyed to A and his heirs to hold to the use of B for 1,000 years,' this use is executed and $\mathrm{B}$ becomes the legal owner, not of the fee, but of the term of years; but if $\mathrm{B}$ assigns it to $\mathrm{X}$ to the use of $\mathrm{Y}$, the latter will have only an Equitable estate. (3) Again the Statute does not apply where there is an acti.:e trust. "I convey land unto A and his heirs, to the use that they shall sell the land and divide the proceeds among my children, or upon trust that they shall so sell and divide. The Stat- ute has nothing to say to this case. You do not find one person seized in trust for another person, you find A seized upon trust to make a

sale." The test seems to be, does the instrument merely tell A that

$\mathrm{B}$ is to have the enjoyment or does it impose upon A some special duty in regard to the property as to manage and control it, and col- lect and pay the profits to the beneficiary?; if the latter the trust is active, not passive, and the Statute of Uses does not thrust the legal title on the beneficiary. (4) Finally after Tyrrell's Case in 1557, it was held that the Statute exhausted itself in executing the first use, and so, in the case of a use upon a use, it did not execute the second use. ${ }^{17}$ This however is a matter that applies to conveyancing.

Again no filing or recording of the tmst instrument is necessary to make the trust valid, at least as to the parties or those who know or ought to know of its existence or terms. ${ }^{138}$

The trust deed in the Sugar Trust case provided that "The cus- tody of the deed was to be in the president of the board, with sole and independent control, and not to be shown to any corporation, firm or person whatsoever except by express direction of the

board." ${ }^{139}$ If it is required to be put in the form of a deed, as in some states, then, of course, it must conform to the statutes relating thereto, and those relating to registration and recording such deeds, in order to furnish constructive notice. But these rules are simple, definite and certain, and easily complied with. $14^{\circ}$ Unless the trust is to do business in an artificial name, or as a partnership, and there are statutes requiring registration, there are no other statutes except in a few states, affecting the creation of trusts, except those relating to perpetuities. These will be referred to in other connections.

Again no fees are to be paid to the state, or other officers, except recording fees when the instrument is a deed of conveyance. Of course if the leg-al estate in land is conveyed in trust, the rules relat ing to the conveyance of the legal title to the trustee, apply just the

\footnotetext{
ur Maitland, Equity, 35-38; Tyrrell's Case, 2 Dyer, 155a, pl. 20, Kenneson, Cases, 37.

"' Carson v. Phelps, (1873), 40 Md. 73.

1n People v. North River Sugar Ref. Co., (1890), 121 N. Y. 582, 18 Am. St. R. 843,

1 Wilgus, Cases, 100

" 039 Cyc. 55-56.
} 
c;ame as thev apply to a conveyance of land to any other party. And in general vhatever rules apply to the transfer of any particular kind of property, to another person, will apply when such is to be conveyed to a trustee in t rust. ${ }^{141}$ And a promise to create a volun- tary trust will not be enforced. The rules we have been discussing apply only to the creation of the trust estate itself.

It seems here again that the balance of simplicity so far as formalities of creation are concerned is in favor of the trust.

Wib. 
II.

\section{Parties to Be Incorporated:}

Coke's second requisite of corporate existence was parties to incorporate, and he indicated that these might be either natural or artificial. It seems now that the latter, i. e. corporations cannot, unless authorized expressly or by necessary implication be either an in-
corporator or member of another corporation.u General incorporation laws contemplate incorporators and members. The former are persons, in the case of business corporations, whose function it is to bring the corporation into existence under the statute; they may or may not themselves become members by taking stock. When the corporation is organized, their functions, as incorporators, cease.a ${ }^{2}$ On the other hand the members are those who become such by ownership of stock, and in the beginning, this ownership is acquired through a subscription. If this is made after the corpora- tion is created, and capable of contracting, the ordinary rules of con- tract may apply.m

In most cases, however, there can be no corporation until mem- bers are secured, and this must be either before or contemporan- eously with the coming into existence of the corporation. This sit- uation has puzzled the courts exceedingly. There are numerous views; (1) Such a preliminary agreement has no force and effect, unless it strictly conforms to the statute, as signing and acknowledg- ing the incorporation paper ; iu (2) That it is a valid contract from the time the requisite amount is subscribed, from which a party can- not thereafter withdraw and which is enforceable against the estate of one, who dies before the corporation comes into existence and accepts it ;145(3) That such a preliminary subscription is a mere withdrawable offer, revocable by death or insanity, at any time be- fore the corporation comes into existence and accepts it expressly or

- Continued from December issue.

ma Denny Hotel Co. v. Schram (1893) 6 Wash. 134, 36 Am. St. R. 130, 1 Wilgus, Cases, 5s 3. Note, 1b., p. $88 \mathrm{~g}$.

.. Nickum v. Burkhardtt, (1897) 30 Ore. 464, 6o Am. St. R. 822, 1 Wilgua, Cases, 391.

1" Southwestern State Co. v. Stephens (1909) 1;J9 Wis. 616, 131 Am. St. R. 1074, 29 I,. R. A. (N. S.) 92,120 N. W. 408.

$\mathrm{M}<$ Sedalia, Warsaw etc. Co. v. Wilkerson, (1884) 83 Mo. 235, 1 Wilgus, Cases, 459; Coppage v. Hutton (1890) 124 Ind 401, ' $l$ I,. R. A. 591, 1 Wilgus, Cases, 469. 491

.. Tonica \& Petersburg R. R. Co. v. McNeeley (1859) 21 Ill. 71, 1 Wilgus, Cases, 
impliedly ;uc (4_) That such a subscription is a mere withdrawable offer to the future corporation, but a contract among the subscribers. $1 \mathrm{H}$ vVhere the courts have not already passed on it, it is impossible to tell which view they will take. Of course if all ${ }^{1}$ goes well, and the corporation is duly formed and accepts the subscriptions made, they will be binding, but until that time there is always great uncertainty from the possibility of death .or withdrawal of a subscriber. The difficulty of the courts is that "it takes two to make a contract," and, since the corporation cannot be bound until it comes into existence and has proper officers to bind it, the other party cannot be bound. To get around this view subscriptions are some- times made with a trustee for the unborn corporation, which a court of equity will enforce in its favor whenever the corporation comes

into existence. ${ }^{14}$

\section{Parties to a Trust:}

This again shows the simpler theory that underlies the trust. If A gives money or other property to $\mathrm{B}$, in trust for $\mathrm{C}$, or even if A declares that he holds money or other property in trust for C,$\mathrm{C}$ whether in existence at the time or not, whenever he comes into existence, at least if within the rule relating to perpetuities, can enforce the trust in equity. In other words only one party or person is necessary to declare a trust ; all the trustee has to do is to accept it expressly or impliedly, and the beneficiary does not have to do that. All that is required is for the settlor to express an intent to create a trust, and designate some one a trustee, and some one a beneficiary.1t 9

Of course this declaration of trust must be distinguished from a gift. If I write a letter to my son saying "I give you my Blackacre estate, my lease-hold house in the High Street, the sum of $£ 1000$. Consols standing in my name, the wine in my cellar," this does not create a trust, nor does it.make a valid gift for a letter will not oo to make such conveyances; even if I execute a deed covenanting to convey and assign these things, there is not yet a trust nor a perfect gift, and the reason is "I make it clear I do not intend to make my-

\footnotetext{
1"' Bryant's Pond Steam Mill Co. v. Felt (1895) 87 Me. 234, 47 Am. St. R. 323, 1 
self a trustee, I mean to give" instead, and an intention to give, without delivering the gift is not a gift. "The two intentions are very different, the giver means to get rid of his rights, the man who is intending to make himself a trustee intends to retain his rights but to come under an onerous obligation." "An imperfect gift is no declaration of trust."!o

"Every person who can hold and dispose of any legal or equit- able estate or interest in property, may create a trust in respect of such estate or interest,"-the state, a private corporation, married women, an infant at least till he avoids it, and aliens and non-resi- dents.1"1 Still further it is the constitutional right under the Fed- eral constitution of a citizen of one state to constitute a citizen of another state a trustee of his property real or personal,

wherever the property is located. The Indiana statute forbidding

this was declared unconstitutiona $1 . .^{152}$

So too any kind of property may be held in trust; real, personal, legal, equitable, in possession or in action, (if assignable), in remainder, reversion, or expectancy, domestic or foreign, can be the subject of a declaration of trust, subject to the rules above given. ${ }^{1 .} 3$

Any one capable of holding property, may be a trustee, an infant, married women, corporation, or alien, or even a person of unsound mind. And in the case of an infant or lunatic, trustee, a court of

equity can vest the title in some suitable person to carry out the trust. One of several beneficiaries may be a trustee if the settlor so appoints. ${ }^{154}$

So too any one can be a beneficiary,-infants, married women, corporations, unincorporated bodies, residents or non-residents,

any one capable of taking and holding any kind of property and no acceptance by the beneficiary is necessa ry. ${ }^{155}$

The other three requisites of corporate existence named by Lord Coke,-name, place, and proper words, along with some others are provided for under general laws in the Incorporation Paper. This usually requires (I) the name, (2) the place, (3) the purpose, (4) the capital stock, (S) the number of directors, and (6) the duration

\footnotetext{
,.. Maitland, Equity, pp. 73, 74.

111127 Am. \& Eng. Encyc., 1st Ed. 13.

m Scars, Trust Estates etc., p. 1q4; Farmers' Loan \& Trust Co. v. Chicago etc.

Ry. Co. (1886) 27 Fed. Rep. 146; Roby v. Smith (1891) 131 Ind. 342, 20 N. E. 1093.

,., 27 Am. \& Eng. Encyc. 1st Ed. 24, 25. Note, Ames, Cases, p. 193.

, .. 27 Am. \& Eng. Encyc. ISi Ed. 16, 17; Cook, Trusts \& Trustees, 1 IIO·II8.

1'"27 Am. \& Eng. Encyc. 1st Ed. 23; Ames, Cases, pp. 215-231; Kcnneson, Cases, 90-97; Loring, Trustees Handbook, p. 15 (3d Ed.); Connecticut Riv. Sav. Bank v. Albee (1892) 64 Vt. 571, 33 Am. St. R. 944.
} 
to be statedm The purpose of course of this Incorporation Paper

is to give definite form to a particular corporation,-to make specific for a single corporation what is general and applicable to all orporations of that class.

Although as we have seen no formal instrument is necessary to the creation of a valid trust, yet in the cast of an express trust for business a deed or declaration of trust is drawn up: (I) Providing for a name; (2) Designating trustees, and providing for their succession; (3) Providing for the raising and conveying the trust res or fund to the trustees, and defining their rights, powers and duties in reference thereto; (4) Providing for the issue of transferable certificates to those who are the cestuis que trust, in proportion to their respective beneficial interests in the property and profits; (5) Providing for division of profits; (6) Limiting liability of trustees

and beneficiaries; (7) Fixing the duration, and providing for disso-

lution at the termination of the trust. ${ }^{167}$

These are so similar to the requirements of the incorporation paper that they may be taken up in order and COJl?.pared with some detail.

\section{Corporate Name:}

It was long ago said that the corporate name is a baptismal one, and of the very. befng of the corporate constitution. It is now universally required to be stated in 'the incorporation paper, although it perhaps could be acquired under the common law by user. When rightfully acquired the corporation is considered as having a fran- chise therein, with the same exclusive right to its use in the incor-porating state that it would have in a trade mark, including the right to enjoin its use by another domestic corporation. In several states particular provisions exist in relation to the selection and publication of the corporate name that must be strictly complied with. It has been held that a change of corporate name without au- thority, makes the members liable as partners. ${ }^{18}$

\section{Trnst Name:}

Jn the absence of a statute forbidding, a natural person may do business in his own name or in any name he pleases to assume as a business name, so long as it does not infringe another's right in a

\footnotetext{
"'" 1 Wilgus, Cases, pp. 435-440.

111 Conyngton, Corporate Organization, p. 366.

$1 " 1$ Wilgus, Cases, pp. 816-829.
} 
name already in use by the latter. ${ }^{1}{ }^{9}$ Since the trustees are natural persons, they may choose such name in which to carry on business if they so desire, or the name may be, probably should be and usually

is designated in the deed of trust, as for example, a trust deed in which Richard Olney, $1 \backslash$ foorefielJ Storey and William F. Beal are trustees (and therefore likely to have been drawn with the utmost legal skill) provides: "49. The trusts of these presents may be collectively designated for all purposes thereof as the Old South Build-ing Trust, and the Trnstees may for the like purposes be referred to as the Trustees of the Old South Building T rust." 100

Another signed by similarly distinguished lawyers, provides;

"First. The trustees, in their collective capacity, shall be designated, so far as practicable, as the ".l\fassachusetts Electric Companies," and under that name shall, so far as practicable, conduct 11 business and execute all instruments in writing, in performance of their trus t."

Some states have statutes, as has Michigan, providing that "No person or persons shall hereafter carry on or conduct or transact business in this state under any assumed name, or under any designation, name, or style, corporate or otherwise, other than the real name or names of the individual or individuals owning, conducting, or transacting, such business, unless such persons shall file in the office of the clerk of the county or counties in which such person or persons own, conduct, or transact or intend tc own, conduct or transact sl,]ch business, or maintain an office or place of business, a certificate setting forth the name or names under which such bus- iness owned is, or is to be conducted, or transacted and the true or real full name or names of the person or persons owning, conduct- ing or transacting the same, with the home and post office address or addresses of said person or persons," ${ }^{102}$ under specified penalty

for failure. By a later provision this was specifically extended to partnerships, and no change in name shall be made until a new certificate shall be filed giving the facts, the old members remaining liable until this new certificate is filed. ${ }^{103}$

This of course would apply to trustees carrying on business under an artificial name. And presumably, also, if the trnst is so organized

\footnotetext{
,.. Sparks v. Dispatch Transfer Co. (1891) 104 Mo. 531, 24 Am. St. R. 351. Note, 132 Äm. St. R. 571. Mutual Benefit Life Ins. Co. v. Cummings, - Ore. -, 133 Pac. I 169, 47 L. R. A. N. S. 252

,.. Cor.yngton, Corporate Organization, Form 62.

.11 Sears, Trust Estates, etc., p. 287.

,., Public Acts, Mich. 1907, No. 101, p. 119.

„.. Public Acts, Mich. 1913, No. 164, p. 286.
} 
as to make the beneficiaries partners, all their names would have to be given. This however should and can be avoided. Such state- ments as the above are generally required in annual reports of cor- porations, and are not more onerous than they are.

\section{Corporate Domicile:}

I have already referred to the uncertainty of the statutory provis- ions relating to place or location. Where the New Hampshire stat- ute provided that the incorporation paper should state the "place in which its business is to be carried on," and the paper drawn by a supposedly competent attorney, stated "the places of business were Nashua in New Hampshire, and East Brookfield, in 1\Iassa-

chusetts," and the manufacturing business was done at East Brookfield, and the corporate meetings held at Nashua, the 1\Iassachu- setts Supreme Judicial Court, held there was no corporation de jure, de facto, or by estoppel, and the treasurer was individually liable on a note given as the corporation's note. ${ }^{10}$ So too corporations are

frequently dissolved for failure to maintain a domiciliary office in the incorporating state, whether the statute so requires or not. It was formerly held that corporate stockholders' meetings coul $<1$ not lawfully be held outside of the creating state because in the very nature of things the incorporating statute conferring such a privilege or franchise, is necessarily inoperative beyond such state, and out- side of such state the assembled stockholders are possessed of only their natural powers. ${ }^{166}$ This doctrine is gradually passing away, and in the absence of statutory provisions controlling, and with pro- visions in the incorporation paper so authorizing, it is now reas- onably safe to hold shareholders meetings outside the creating state. ${ }^{167}$ However there are so many conflicting decisions and statu- tory provisions that it is never wise to advise such to be done. ${ }^{168}$

\section{Trust Domicile:}

Upon the other hand since Trustees act not under any special privilege or franchise from the state, but under their common law and constitutional right as citizens of one state to do business there

\footnotetext{
,.. Montgomery v. Forbes, (1889) 148 Mass. 249, 19 N. E. 342, 1 \Vilgus, Cases, 594- 1..

Frost, Incorporation and Org. of Corp., pp. 64, 65 (4th Ed.).

'"'" Miller v. Ewer (1847) 27 Mc. 509, 46 Am. Dec. 619, 1 Wilgus, Cases, 841.

${ }^{157}$ Mis90uri Lead etc, Co. v. Reinhard (1893) 114 Mo. 218, 35 Am. St. R. 746, 1 Wilgus, Cases, 844; Graham v. Boston etc. R. R. (1886) 118 U. S. 161, 1 Wilgus, Cascs, 846, note p. 847.

ioa Machcn, Corp. § 1212.
} 
or in another, there is no difficulty as to "place of business," and no place of business - is usually stated, further than to designate the city in which annual or other meetings are to be held. Here again the Trust is simpler. ${ }^{160}$

\section{Corporate Purposes:}

Incorporation statutes frequently provide for incorporation "for any lawful pu'rpose" with certain exceptions, usually of a public service character. There is frequent difficulty in determining wheth- er two or more purposes can be joined in one incorporation paper; the statutes in some states expressly authorize this; in some states the state officials so construe their ambiguous statutes; in bthers the statutes divide business into classes, which cannot be joined; in still other states only one purpose or general object can be claimed; while in still others, the name of the corporation must indicate the various purposes. This serves to indicate the confusion, and the difficulty encountered here. $17^{\circ}$ This is mitigated however somewhat by the rule that things that cannot be properly claimed are mere surplusage, and can be rejected. This however would not help out an incorporation paper where two objects are joined when only one is permitted, but either of which would be valid if standing alone. Perhaps the corporation would be permitted to elect, and amend the paper, and thereafter carry on the one line of business elected. In any event the "object" clauses of ari important corpor- ation paper requires special skill and care in drawing.

\section{Trust Purposes:}

There seems to be no such difficulty, or in fact no such limitations, applying to Trusts. They can be created to carry on any lawful business or businesses desired, one or many as the parties, the declar- ants and the trustees provide for, unless there are express statutory limitations. They have been created for manufacturing, mining, lumbering, agriculture, transportation, mercantile, real estate, hold- ing shares, disposing of patents, and numerous other purposes. ${ }^{171}$ And as we saw above "Every kind of valuable property, both real and personal, that can be assigned at law may be the subject-matter of a Trust.m Here again with equal attention the purposes for which a Trust may be formed may be more certainly provided for than in similar incorporation papers.

\footnotetext{
.${ }^{1}$ See Forms, given in Sears, Cook (Corp.) and Conyngton (Corp. Organuation).

${ }^{10}$ Frost, Incorp. and Organ. Corps., p. 19 et seq.; Machen, Corps., ti 46-108.

$\mathrm{m}$ Sears, Trust tates etc., p. a53.

${ }^{112}$ Perry, Trusts, 6th Ed., I 67.
} 
For instance in the $1 \backslash$ fassachusetts Gas Companies, the declaration of trust authorized its trustees to engage: ( r) in manufacturing, buying, selling and dealing in coal, oil, coke, gas and all products thereof: (2) in manufacturing and supplying gas or electricity or any other agent for light, heat, power or other purposes; (3) in ac- quiring; owning, managing, exchanging, selling and dealing in the stocks, shares and securities of corporations, trusts or associations, engaged in whole or in part in any business above mentioned, or in owning and operating railways or railroads or transporting pas- sengers, merchandise, mails or express matter, or in manufacturing, selling or repairing machines, equipments supplies or other articles used by corporations, trusts or associations of any of the classes

above mentioned. ${ }^{* * *}$ (4) in any business similar in character to that above mentioned which the trustees may deem expedient." and

to acquire, hold and dispose of the stocks of such in stitutions. ${ }^{1}$

\section{Corporate Stock:}

The theory of the capital stock of a corporation is that the power to have such, or increase or decrease it, is a corporate franchise, and must be expressly conferred by the state, or otherwise it does not exist. ${ }^{1}$ ${ }^{74}$ Incorporation statutes frequently fix maximum and mini- mum limits, and sometimes limit indebtedness to the amount of capi- tal stock, also special provisions are almost always made in reference to increase or decrease of the same, otherwise unanimous consent of shareholders, as well as the consent of the state would beneces-

sarym Under all the incorporation laws, the incorporation paper must state the number of shares, and the par value thereof (except now in New York) and these cannot be changed except by an amendment made to the articles of incorporation. In the absence of statutory provisions preventing, in the original organization of the company, preferred and common stock may be provided for in the incorporation paper, but not so afterward except by uanimous consent, unless there are statutory provisions making other regula- tions.176 In several states as in Michigan the statutes provide for a certain kind of redeemable pref erred stock with a limited dividend; in such states other kinds of preferred stock, or with greater divi- dends cannot be provided for. In some states the statute. because

\footnotetext{
171 Sears, Trust Estates, p. 303.

"'Cooke v. Marshall (1899) 191 Pa. St. 315, 1 Wilgus, Cases, 761.

m Railway Co. v. Allerton (1873) 85 U. S. (18 Wall.) 233, Wilgus, Cases, 442, note 763 .

m Keht v. Quicksilver Mining Co. (1879) 78 N. Y. 159, I Wilgus, Cases, 790, note 793; Campbell v. Zylonite Co. 121 N. Y. 455.
} 


\section{- 39-}

the common law was otherwise, expressly provides "that each shareholder shall be entitled to one vote for each share held." In such a state can non-voting preferred shares be created? This is answer- ed differently in different jurisdictions. ${ }^{177}$ In some states there is a statutory liability attaching to the ownership of stock, and our Supreme Court has just held that when a corporation organized in one state having no such statutory liability, is expressly authorized to do business in a state having such liability the shareholders be- come liable thereon for business done in such state. ${ }^{178}$ This makes stock holding in corporations organized to do business throughout the United States a precarious matter.

\section{Trust Stock:}

How is it with Express Trusts? Can they be created with a capital stock represented by transferable shares? Or can the property held in trust by the trustees be represented by shares issued by the trustees, transferable, so as to give purchasers the same rights as original beneficiaries?

There is no doubt now, but that at Common Law, under merely their power to .contract, individuals may between themselves engage in business together, each contributing property thereto, and take certificates representing their interests, which they may if the agreement so provides transfer to others. For 100 years or so, 1720 to

1825, the English Bubble Act forbade this, but this was repealed in England, and was never, or if at all, only to a very limited extent in force in this country. The courts in this country have held from the beginning that this could be done, $1^{70}$ and now hold, that although by constitutional provisions "corporations can be created only under general laws" and corporation is defined in the constitu- tion to "include all associations and joint stock companies having any of the powers and privileges of corporations not possessed by individuals or partnerships," and there is no statute authorizing the creation of joint stock companies with transferable shares, still, such institutions can be created by contract among individuals under the exercise of their common law rights and not be corporations. Such was the holding in a well considered Idaho case, following many similar decisions in other states. ${ }^{180}$ There is therefore no law against doing this. Still further we have already seen that the in-

111 State v. Swanger, 190 Mo. 561, 89 S. W. 892; Colonial Printing etc. Co. v. Duns• muir, 32 Can. Sup. Ct. 679.

${ }^{171}$ Thomas v. Matthiessen (1913) 232 U. S. 221.

1" 1 Wilgus, Cases, note p. 175. Sears, Trust Estates, fl 52-54,

${ }^{190}$ Spottswood v. Morris (1906) 12 Id. 360, 6 L. R. A. (N. S.) 665, 85 Pac. 1094. 
terest of a beneficiary is substantially a property right inheritable, descendible, and transferable as other rights are. The 9th section of the English Statute of Frauds required an assignment to be in writing; and since the beneficiaries' rights are not those of joint or cotenants in the trust fund, but wholly incorporeal and intangible, just what the trust declared provides, the most natural way to represent them is by a certificate, and the most natural and convenient way of transfer is by an assignment of the certificate. In Estate of

Oliver, the Pennsylvania Supreme Court, held that the interest of the stockholder "was an interest in the profits made. He had no title to the land bought by the trustees for the company, as a tenant

in common or otherwise and could neither convey nor encumber it. His interest in it was personal estate and -the extent of that interest was shown by his cerificate of stock." 181

The following are illustrations of the stock provisions in a few Trusts:-

"Central Massachusetts Light and Power Co. The beneficial interest in the trust created by its agreement and declaration of trust is divided into 6,500 preferred shares and 6,500 common shares. The latter have no par value. The former have a par value of $\$ 100$, are entitled to cumulative preferred dividends of 5 per cent the first year and increasing thereafter yearly to 6 per cent after May 15, 1918. The preferred shares have a preference in liquida-

tion and are entitled to $\$ 1 \mathrm{Jo}$ if the trust is terminated within two years, and to amounts increasing thereafter yearly up to $\$ 125$ if the termination occurs after May 15, 1918."182

The Worcester Railways and Investment Company issued "negotiable certificates or evidences of interest for 60,000 shares, each share representing a fractional beneficial interest of $1 / 60000 \mathrm{in}$ " its property, the trustees having discretion to fix the dividends thereon.1ss

The capital of the Massachusetts Light and Traction Companies, is "divided into 100,000 shares of the par value of $\$ 1.00$ each, bearing 5 per cent. non-cumulative dividends, to be designated as "preferred A stock," 50,000 shares of the par value of $\$ 5.00$ each, bearing 6 per cent. non-cumulative dividends, to be designated "preferred B stock," and 10,000 shares of the par value of $\$ 25,000$, of common stock." 184

181 Oliver's Estate (1890) 136 Pa. 43, zo Am. St. R. 894.

${ }^{181}$ Report (No. 1788 House) of Special Commission, Mass., on Voluntary Associa. tions (1913) p. 40.

111 lb. p. $z o$.

"'1b. p. 44- 
It would seem again here that the Express Trust is much more fltxible than the usual corporation provisions are in reference to shares, there being no state to interfere, or statute to follow, anri the

whole matter can be moulded to suit the parties, and may be changed in any way or at any time, in accordance 'with such provisions as may be inserted in the trust agreement. The only point of difficulty here is in reference to partnership liability, a matter which is considered later on.

\section{Corporate Directors:}

Statutes usually require the number to be stated, and when once fixed can be changed only by an amendment regularly adopted. Statutes also usually require them to be shareholders to the extent of a few shares. Being elected there is no power of removal, unless expressly provided for in the statute, incorporation paper, or by- laws. By perhaps all business corporation statutes there $\mathrm{mmt}$ be directors, and in them the ordinary powers of the corporation are vested. ${ }^{186}$ They however have no legal or equitable title to tne cor-

porate property. They act only in duly called meetings. ${ }^{187}$ Their functions are sui generis, and have been likened to those of agents, trustees or mandatories of the corporation, but perhaps they are strictly neither. ${ }^{188}$ Directors, however, are not agents of the share- holders, and except in certain peculiar situations are not generally said to be in a position of trust toward them. ${ }^{199}$ Courts are not in accord upon the degree of care and diligence required of directors, one line of authorities saying that the care and diligence that an ordinarily prudent man takes of his own business, is required, while another line of authorities says, since they get no pay, no greater care is required than that required of a gratuitous bailee. ${ }^{190}$

They have no authority to sell or dispose of the corporate capital or property, except such as is properly done in the ordinary course of business. For defaults of the directors affecting all the shareholders alike, they are primarily liable only to the corporation, and

\footnotetext{
!. In the Matter of Election of Directors, 63 N. J. L. 168, 2 IVilgus, Cases, p. 1744,

"'" Blood v. La Serena, 113 Cal. 221; Metropolitan Elev. R. R. Co. v. Manhattan El. Ry. Co. (1884) 11 Daly (N. Y.) 373, 1 Wilgus, Cases, 694, note 702.

'"' Bank of Little Rock v. McCarthy ( 1892) 55 Ark. 473, 29 Am. St. R. 6o, 1 Wilgus, Cases, note 850 .

,.. Allen v. Curtis (1857) 26 Conn. 456, 2 Wilgus, Cases, 1727; Ellis v. Ward (18go) 137 Ill. 509, 2 Wilgus, Cases, 1729; Wallace v. Lincoln Sav. Bank (1891) 89 Tenn. 630, 24 Am. St. R. 625, 2 Wilgus, Cases, 1731.

$>\bullet^{\circ}$ See "Purchase of Shares of Corporation by a Director from a Shareholder," by H. L. Wilgus, 8 Mich. Law Rev. (Feby. 1910) p. 267.

$1^{10}$ North Hudson Building \& Loan Assn. v. Childs (1892) 82 Wis. 46o, 33 Am. St. R. 57, 2 Wilgus, Cases, 1737. Sec also ${ }_{2}$ Wilgus, Cases, pp. 1874-1888.
} 
only when they so control the corporation as to prevent it from bringing a proper action to protect itself amounting to a substantial breach of trust, can the shareholder bring a representative suit in equity to prevent a failure of justice. Courts of equity have no

special jurisdiction over directors merely as such. It is only when

there is a breach of trust upon their part, that they can be called to account in equit $\mathrm{y} .{ }^{191}$

\section{Trustees of Trusts:}

In case of the Trust, the Trustees stand, so far as control and management are concerned, if the Trust agreement so provides, in a position somewhat analogous to that of directors in a corporation. They, however, exercise control, because they are the owners of the property, and not the agents of the beneficiaries, or of any one else. They act as owners, but as owners that are obliged to render an account in equity not merely to all the beneficiaries as a whole,

but to each and every beneficiary; for the beneficiary's right is individual, and in personam, and enforceable in equity primarily, not secondarily, against the trustee. ${ }^{192}$

A trustee has whatever estate either legal or equitable is neces- sary for him fully to carry out the trust created but no further $;^{193}$ and (1) "A trustee is bound to do anything that he is expressly bid- den to do by the instrument creating the trust. (2) A trustee may safely do anything that he is expressly authorized to do by that in- strument, even loan or invest money without adequate security.

(3) A trustee is bound to refrain from doing anything that is ex- pressly forbidden by that instrument. (4) Within these limits a trustee must play the part of a prudent owner and a prudent man of business," not as if he had himself alone to consider, but also "for the benefit of other people for ,vhom he felt morally bound to provide." 19

Upon the other hand, however, just because the trustee is owner of the property, if the trustee dies intestate his estate devolves upon his heir or personal representative if he had a fee; so also he can devise the estate, or convey it inter vivos, ${ }^{19}$ in fact "At law the trustee has all those powers of alienating inter $\cdot v i \cdot v o s$, mortgaging and

1111 Dodge v. Woolsey (1855) 59 U. S. (18 How.) 331, 1 Wilgus, Cases, 88; Hawes v. Oakland (1881) 104 U. S. 450, 2 Wilgus, Cases, 1716.

111 Ames, Cases, pp. 235-278.

N. E. 166.

"' Maitland, Equity, p. 98; Cook, Trusts \& Trustees, I 127; Whiteley v. Learoyd, 33 Ch. D. 355,12 A. C. 722, 25 Eng. Ru!. Cas. 326.

${ }^{191}$ Maitland, Equity, pp. 86-go. 
so forth that he would have were there no trust in existence," but of course any heir, devisee, executor, administrator or party taking with notice is Loun $<1$ by the trust. To prevent these results several trustees arc appointed to hold as joint-tenants, with its attendant surv iYorship. ${ }^{106}$

Unlike directors the act of a majority of trustees does not bind the

minority., all must join in a conveyance, or - in a receipt. They are not at all agents for one another, nor can one shelter himself by saying he was out voted, if he, nevertheless, acquiesced in the action taken. ${ }^{197}$ Of course, however all of these matters can be modified to suit the wishes of the settlor.

The following from the declaration of trust of the $1 \backslash$ fassachusetts Gas Companies,-a manufacturing tmst,-indicates what may be done : 108

"The trustees shall hold the legal title to all property at any time belonging to this trust, and subject only to the specific limitations herein contained, they shall have the absolute control of the conduct of all business of the trust; and the following enumeration of specific d,1ties and powers shall not be construed in anyway as a limitation upon the general powers intended to be conferred upon them.

"The Trustees shall have authority to adopt and use a common seal ; to make all such contracts as they may deem expedient in the conduct of business of the trust; from time to time to release, sell, exchange. or otherwise dispose of, at public or private sale, any or all of the trust property, whether real or personal, for such prices either in cash or the stocks, shares, or securities of other corpora- tions. trusts or a sociations and upon such terms as to credit or oth- erwise as they may deem expedient; to guarantee or assume the ob- ligations of other corporations, trusts or associations and to enter into such agreements by way of indemnity or otherwise as they may deem expedient in connection with the acquisition of property from the subscribers as hereinbefore provided or otherwise; to confer, by way of substitution, such power and authority on the President, Treasurer, Secretary, and Executive Committee, and other officers and agents appointed by them, as they may deem expedient; to bor- row money for the purposes of the trust and give the obligations of the Trustees therefor; to loan any money from time to time in the

${ }^{11}$ Maitland, Equity, p. 93.

•. Reichert v. Missouri etc. Coal Co. (1907) 231 Ill. 238, 121 Am. St. R. 307, 83

N. E. 166; :Mattison v. Mattison (1909) 53 Ore. 254, 100 Pac. 4, 133 Am. St, R. 8:z9; Adams' Estate (1908) :z21 Pa. 77, 7a At!. 438, 128 Am. St. R. 7:z7, Estate of Fesmire, 134 Pa. St. 67, 19 Am. St. 676.

"'" Sears, Trust Estates etc., p. 303. 
hands of the Trustees, with or without security, on such terms as

they may deem expedient; to subscribe for, acquire, own, sell or otherwise dispose of such real or personal property including the stocks, shares, and securities of any other corporations, trusts, or associa- tions, as they may deem expedient in connection with the purposes of the trust; to vote in person or by proxy on all shares of stock at any time held by them, and to collect and receive the income, interest, and profits of any such stock or securities; to collect, sue for, re- ceive, and receipt for all sums of money at any time becoming due

to said trust; to employ counsel and to begin, prosecute, defend, and settle suits at law, in equity or otherwise, and to compromise or re- fer to arbitration any claims in favor of or against the trust; and in general to do all such matters and things as in their judgment will promote or advance the business which they are authorized to carry on, although such matters and things may be neither specifically authorized nor incidental to any matters or things specifically author- ized. In addition to the powers herein granted the Trustees shall have all power with reference to the conduct of the business and management of the property of the trust which are possessed by directors of a manufacturing corporation under the laws of l\Iassachusetts.

"So far as strangers to the trust are concerned a resolution of the Trustees authorizing a particular act to be done shall be conclusive evidence in favor of strangers that such act is within the power of the Trustees; and no purchaser from the Trustees sh.all be bound to see to the application of the purchase money or other consideration paid or delivered by or for said purchaser to or from the Trustees.

"Stated meetings of the Trustees shall be held at least once a month, and other meetings shall be held from time to time upon the call of the President or any three of the Trustees. A majority of the Trustees shall constitute a quorum; and the concurrence of all the Trustees shall not be necessary to the validity of any actioQ taken by them, but the decision expressed by a vote of a majority of the Trustees present and voting at any meeting shall be conclusive."

Other provisions authorize the adoption of by-laws, election of officers, and executive committee, and agents, accepting resignations, removing officers, filling vacancies, keeping records, etc.

Also "The Trustees shall not be liable for any error of judgment or for any loss arising out of any act or omission in the execution of this trust, so long as they act in good faith, nor shall they be per- sonally liable for the acts or omissions of each other, or for the acts or omissions of any officer, agent, or servant elected or appointed by 


$$
-45-
$$

or acting for them; and they shall not be obliged to give any bond to secure the due performance of this trust by them.

"Any Trustee may acquire, o,vn, and dispose of shares in this trust to the same extent as if he were not a Trustee."

\section{Corporate Life or Duration:}

IVe have seen that corporations were often said, to be immortal. This of course meant that there was continuous or perpetual suc-

cession for an indefinite and unlimited time unless the corporation was dissolved in some of the ways known to the law,-loss of all members, act of Parliament, surrender of franchises, or quo warranto for misuser or non-user. ${ }^{10}$ This is still the law, unless there are constitutional or statutory provisions to the contrary, but there are such in nearly ever state, the limit fixed being usually from 20 to 50 years, and in many cases the proposed duration must be stated in the Incorporation Paper. In many states a renewal may be had for a like period. With us the Legislature has no right to dissolve unless the power to do so is reserved to the State. ${ }^{200}$ However, through quo warranto proceedings for violation of duty injurious- ly affecting the public, the courts may pronounce judgment of dis- solution.201 During the whole of its prescribed life, the corporation is said to have perpetual or continuous succession, and remains the same corporation regardless of any change in membership.

\section{Trust Duration:}

In this respect, because of the "rule against perpetuities," the corporate organization seems simpler than the Trust form. This rule in all its applications is exceedingly intricate and technical, and frequently papers, especially wills, drawn by the best lawyers have contained provisions that have been rendered ineffective because offending against the rule. In the matter of an ordinary business trust, however, while perhaps a perpetual or immortal existence can- not be acquired, an existence that is as long as or in many cases much longer than the ordinary corporate life can be obtained.

The English rule seems to have two branches, one relating to the vesting of future estates, and the other to trusts for accumulations. These may be stated: (1) "Every future contingent estate limited

"'" State v. Payne (1895) 129 Mo. 468, I \Vilgus, Cases, 830; Hoston Glass Manulac tory v. Langdon (1834) 24 Pick. (Mass.) 49, 35 Am. Dec. 292, I \Vilgus, Cases, 866.

200 Trustees of Dartmouth College v. Woodward (1819), 4 Wheat. (U. S.) 518, I VVilgi,s, Cases, 708.

${ }_{0.0}$ People v. Dashaway Association (1890) 84 Cal. 114, 2 Wilgus, Cases, 1298. 
to arise on an event that might possibly happen later than 21 years and the period of gestation afiter the death of persons living at the creation of -the estate is void the day it is created." 202 ( 2) "vVhere property, real and personal, is given to trustees to hold and to receive and invest the rents and profits of the real property and the income of the personal property, and to deliver the property and income at a certain or contingent future time to the beneficiaries, if

that time may possibly happen more than 21 years and the period of gestation after the death of persons living at the creation of the trust,

the direction to accumulate and the gift of the accumulated fund are void absolutely." 203

Neither of these rules $\backslash$-vould seem to prevent the creation of trusts

for indefinite periods, as A grants property to $\mathrm{B}$ in fee to control and manage for $\mathrm{C}$ in fee, for each estate, the legal and equitable, is vested in the respective parties, and they together may at any time if they choose terminate the trust, and together convey an absolute title to the property. ${ }^{20}$

A recent writer however has said "The courts in this country seem to be moving very rapidly toward the general announcement of the rule that trusts of absolute indestructible equitable interests can- not be made to last for longer than lives in being and twenty one years, and that any provision which may by any possibility postpone the term of the trusteeship for longer than that period is wholly void

from the beginning." 20

It has been held in Illinois that where the trustees have the abso- lute power to sell at any time free of the rights of the beneficiaries, the rule does not apply ;206 and likewise in Massachusetts, if the in- come is not to be accumulated, but distributed as it accrues, and where the whole equitable interest is at every moment vested abso- lutely in the shareholders, and can be sold by them at any time, the rule does not apply $;{ }^{207}$ but if the trustees and beneficiaries cannot together convey the complete title without violating the trust, the rule is violated. ${ }^{208}$

In New York the statute provides that "Every future estate shall be void in its creation which shall suspend the absolute power of alienation for a longer period than two lives in being. ${ }^{*} *$ Such

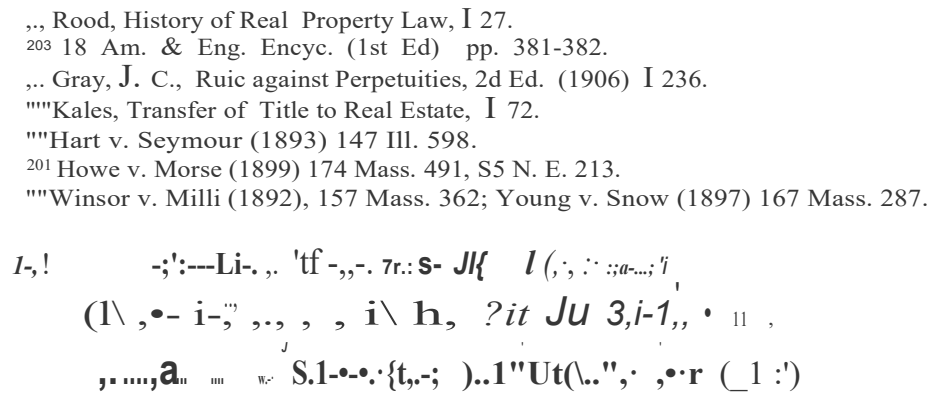


power of alienation is suspended when there are no persons $\mathrm{m}$ being by whom an absolute fee in possession can be conveyed." Under this statute it has been held that if the trust term is longer than the period of two lives in being, but the trustees have at all

times the power to convey the complete title neither the rule nor statute is violated. ${ }^{209}$ And where the trust is for the sole benefit of the settlors or their appointees, the rule does not apply, even though the beneficiaries are infants, or are numerous, and the entire inter- est cannot be disposed of without their consent. ${ }^{210}$

In New York, 1V [ichigan and Minnesota, the period seems to be two lives only; in Wisconsin, two lives and 20 years; in California, Idaho, North and South Dakota, the period is fixed by lives, in

being at the creation, but there is no limitation as to number; in all

other states the period is a "life or lives in being and 21 years thereafter."211 The lives specified may be those of trustees, existing beneficiaries or strangers. ${ }^{212}$

The following are illu trations: The term of the Boston and Worcester Electric Companies is "twenty years after the death of the last. survivor of 27 persons named in the agreement and declaration."213 In the Massachusetts Electric Companies "The- trust is to continue for the term of 21 years from the date of the agreement, unless the holders of at least two thirds of the shares then outstanding shall at a meeting called for that purpose vote for its ' termination or continuance."214 The Massachusetts Northern Railways put it: "The trust-is to continue for the term of twenty years after the death of the last survivor of ten persons" named, six of whom were the sons and daughters of the other four, three of whom were trustees; but at any time by a vote of $2 / 3$ of the outstanding shares in a meeting called for the purpose, confirmed by the vote of $5 / 7$ of the trustees, the trust can be terminated, and the property be distributed, or be sold and proceeds distributed. ${ }^{21}$

As has been pointed out a succession of trustees can be kept up by means of joint tenancies, or by provisions in the trust-deed, or if necessary to prevent failure by appointment of a court of equity,

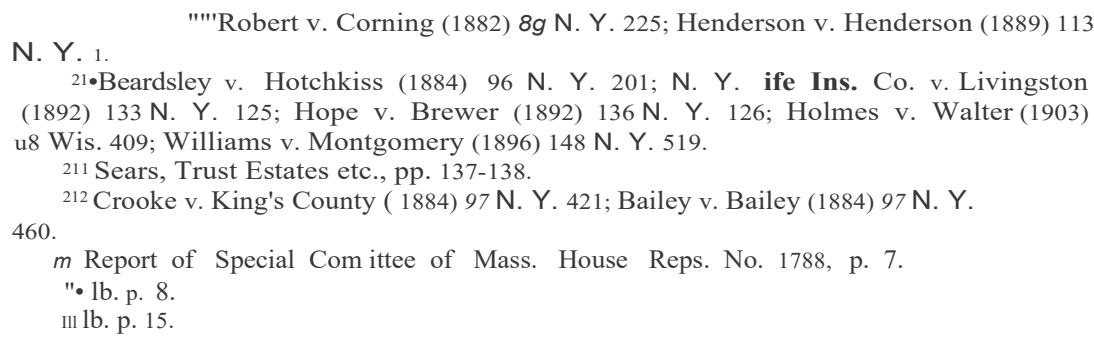


for it is a maxim that a trust shall not fail for want of a trustee. ${ }^{216}$ So too if there is not a special confidence in the person, instead of in the office, of the trustee, no additional conveyances are necessary

to keep up the succession of powers, rights and duties in the trustees. ${ }^{21}$

A little care in the drawing up the trust instrument may make the trust as convenient in this regard as the corporation. ${ }^{218}$

This brings us to a consideration of the corporation and trust obligations and liabilities. Here are important differences, in theory, and great care is necessary in drawing trust agreements or there is danger of unexpected or unusual liabilities.

\section{Corporation Liabilities.}

It results, of course, that because a corporation is a separate person in the law, that its rights and obligations are its own, and not those of any other persons. And this doctrine obtains universally

except when this corporate personality is used to "defeat public convenience, justify wrong, protect fraud, or defend crime." ${ }^{210}$ It follows of course that if the corporation is properly organized, and the shareholders and officers do all they should do, and do nothing they should not do, no one is liable except the corporation for any obligations incurred. The theory is that the creditor must look to the capital, ttock of the corporation for his protection; and this capital stock is frequently called a "trust fund" for the protec- tion of creditors. ${ }^{220} \quad$ Yet this trust fund doctrine has been bitterly assailed, and it is held there is no liability on officers and shareholders, in the absence of statutory provisions, unless there is actual or constructive fraud, or ultra vires, or tortious or illegal acts upon their part. ${ }^{21}$ Of course it is agreed that if there is a trust fund, it is peculiar, unlike ordinary trust funds, since there is no

0.1 Reichert v. Mission etc. Coal Co. (1907) $231111.238,121$ Am. St. R. 307; Dodge v. Dodge (1908) 109 Md. 164, 71 Atl. 519, r30 Am. St. R. 503, note 508; Smith v. Davis (1891) 90 Cal. 25, 25 Am. St. R. 92; U. S. Casualty Co. v. Kaccr (1902) 169 Mo. 301, 69 S. W. 370,92 Am. St. R. 641.

211 Kadis v. Weil (r9r3) r64 N. C. 84,80 S. E. 229. Compare Maryland Casualty

Co. v. Safe Deposit Co. (r91I) rr5 Md. 339, Ann. Cas. 1913 A 1279, note.

${ }^{218}$ See Jiorms given in Scars, Cook (Corp. 7th Ed.), Conyngton (Corp. Organ.).

2U Smith v. Moore (1912) 199 Fed. 689. Sec also 10 Mich. Law Rev. 310; 12 Col. Law Rev. 496.

"'"Wood v. Dummer (1824) 3 Mason 308, 2 Wilgus, Cases, 1847; Scovill v. Thayer (1881) 105 U. S. 143, 2 Wilgus, Cases, 1907; Shields v. Hobart (1903) 172 Mo. 491, 95 Am. St. R. 529, 72 S. W. 669-

221 O'Bear Jewelry Co. v. Volfer (1894) 106 Ala. 205, 54 Am. St. R. 31, 2 Wilgus, Cases, 1852; Hospes v. Northwestern Mfg. Co. (1892) 4,8 Minn. 174, 2 Wilgus, Cases, 1911; Hall v. Henderson (1900) 134 Ala. 455, 63 L. R. A. 673. 
separation of the legal and equitable titles, and no special trusts and confidence existing between the corporation, corporate officers, or shareholders, and corporate creditors. The corporation owns the whole title iegal and equitable to corporate property and the creditor has, merely as shch, no lien upon it either at law or in equity, at

least before insolvency. ${ }^{222}$ And so it is held by the great weight of authority ( in the absence of bankruptcy laws forbidding) that a corporation can lawfully prefer its creditors, even stockholder and director creditors, if it chooses, and there is no actual fraud. ${ }^{228}$

Nevertheless it is to a fund designated capital, or capital stock, and to that only, that creditors can_look for protection. There is however much confusion as to exactly what is included in this fund. It perhaps can now be safely said to include all the corporate property, real, and personal, tangible and intangible, choses in

possession and in action, up to an amount equal to the face value of the outstanding stock, but yet not to that extent, if the corporate capital has been dissipated by misfortune, and not by fault of responsible partiesm

There is however yet some uncertainty as to holding shareholders liable for unpaid stock, or for stock issued for overvalued property, or for dividends paid out of corporate capital.

New York has just held that under the law of that state share- holders in the absence of an agreement to pay up their stock, can- not be held by creditors to pay up. ${ }^{226}$ As to payment of stock by property, one line of authorities holds that in the absence of actual fraud, established by the complainant, the judgment of the direc- tors is final, ${ }^{226}$ as where the three dummy incorporators and direc-

tors holding $\$ 3,000$ of stock in the U. S. Steel Corporation, under the New Jersey law passed a resolution that the property proposed to be turned over to the company was equal in value to the face value of the stock and bonds, $\$ 1,410,000,000$ to be issued for it. The Government experts however think there was $\$ 700,000,000$ water in it. Another view is that it is only a quegtion of fact to be determined by a jury when the question is submitted to them upon the facts put before them, and good faith will not protect;

m Hollins v. Brierfield Coal Co. (18g3) 150 U. S. 371, 2 Wilgus, Caaes, 1868.

:21 Catlin v. Eagle Bank (1826) 6 Conn. 233, 2 Wilgus, Cases, 1815; Corey v. Wads• worth (1897) 118 Ala. 488, 2 Wilgus, Cases, 1836. Compare Rouse v. Merchants Natl. Bank (1889) 46 0. S. 493, 15 Am. St. R. 644, 2 Wilgus, Cases, 1819; Olney v. Conanicut Land Co. (1889) 16 R. I. 597, 27 Am. St. R. 767, :a Wilgus, Cases, 1832.

${ }^{224}$ Am. Life and Acc. Ins. Co. v. Ferguson (1913)) 66 Ore.. 417, 134 Pac. 1029; In

re Wells Estate (1913) 156 Wis. 294, 144 N. W. 174.

m Southworth v. Morgan (1912) 205 N. Y. 293.

:..-. Graves v. Brooks (1898) 117 Mich. 424, 2 Wilgus, Cases, 1950. 


\section{$-\mathrm{SO}-$}

another rule is that a large difference in the actual value of the property and the face value of the stock issued is prima facie evidence of fraud and calls for explanation; ${ }^{21}$ and still another view

is that if the corporation is a "going concern," but nearly "gone," stock may be issued at a discount to takers in order to see, if perchance, it may be revived, at the expense of subsequent creditors. $2^{28}$

So, too, while it was originally held that the directors could not pay dividends to shareholders out of the corporate capital, yet our Supreme Court has held that where shareholders receive such dividends in good faith, supposing they were properly declared and paid out of profits instead of capital they may keep them, ${ }^{229}$ and the creditor must whistle through the corporate whistle to the defaulting direc- tors to make good their loss.

Then too there are statutory efforts to protect creditors, which for the most part are satisfactory to nobody. These are attempts

to make officers and stockholders liable for corporate debts under such varying circumstances that it is difficult to tell what the liability is, whether penal or contractual, $2^{30}$ primary or secondary, ${ }^{231}$, limited or unlimited, separate or joint, or on prior, existing, or subsequent shareholders, $m$ and whether enforceable outside of the state or no t. ${ }^{234}$ So too many states provide that all "fictitious issues of stock or bonds shall be void," yet courts have had great difficulty in giving effect to such provisions, for if the effort to issue stock at a discount is $z$,oid, the statute would then hurt creditors more than in any other way, and defeat its own probable purpose. ${ }^{235}$ On the other hand Montana has a statute that provides that stock may be issued for mining property taken at any value, and such stock shall be deemed to be wholly paid up. ${ }^{236}$

m See cases cited in State Trust Co. v. Turner (1900) 111 Ia. 664, 82 N. W. 1029, 53 L. R. A. 136, 2 Wilgus, Cases. 1953. Compare ${ }_{\mathrm{I}}$ Cook, Corp., H 46-47.

'"'"Handley v. Stutz (1891) 139 U. S. 417, 2 Wilgus, Cases, 1923.

${ }^{221}$ McDonald v. Williams (1899) 174 U. S. 397, 2 Wilgus, Cases, 1981.

:a Wiles v. Suydam (1876) 64 N. Y. 173, 2 Wilgus, Cases, 1981

$m$ Umsted v. Buskirk (1866) 17 0. S. u3, 2 Wilgus, Cases, 1990•

.., Hanson v. Donkersley (1877) 37 Mich. 184, 2 Wilgus, Cases, 1997.

.., Harger v. McCullough (1846) 2 Denio (N. Y.) 19, 2 Wilgus. Cases, 1998; Dank of Poughkeepsie v. Ibbotson (1840) 24 Wend. (N. Y.) 473, 2 Wilgus, Cases, 2001; Foot v. Sinnoclc (1887) 120 Ill. 350, 2 Wilgus, Cases, 2003; Zang v. Wyant (1898) 25 Colo. 551, 2 Wilgus, Cases, 2005.

234 Marshall v. Sherman (1895) 148 N. Y. 9, 2 Wilgus, Cases, 2021; Howarth v. Angle (1900) 162 N. Y. 179, 2 Wilgus, Cases, 2028; Whitman v. Oxford Bank (1900) 176 U. S. 559, 2 Wilgus, Cases, 2018.

Van Cleve v. Berkey (1898) 143 Mo. 109, 42 L. R. A. 593, 2 Wilgus, Cases, 1953.

Compare I Cook, Corp., § 47.

- Civil Code of Montana, § 3824, (Mar. 7, 1895). 


\section{$-51-$ \\ Tmst Liabilities.}

(a) Trustees liability: As has been pointed out, in a Trust, the

tru5tees are the owners of the property to the extent of any estate necessary for them to have under the instrument of trust to enable them fully to execute it. If it therefore gives to them full control, management, and disposition of the property, they acts as owners do, as principals and not as agents of others. ${ }^{237}$ It would naturally follow from this that they bind themselves personally and themselves alone, in the absence of some provision to the contrary. The debts

they incur are their personal debts, not those of the beneficiaries, nor of the trust fund. ${ }^{238}$

As was said by the United States Supreme Court in Taylor v. $D m \bullet i s,{ }^{239}$ "IVhen an agent contracts in the name of his principal, the principal contracts and is bound, but the agent is not. IVhen a trustee contracts as such, unless he is bound no one is bound for

he has no principal. The trust estate cannot promise; the contract is therefore the personal undertaking of the trustee. As a trustee holds the estate, although only $\mathrm{v}$, ith the power and for the purpose of managing it, he is personally bound by the contracts he makes as trustee, el'en when designating himself as such. $* * *$ Of course when a trustee acts in good faith for the benefit of the trust he is entitled to indemnity himself for his engagements out of the estate in his hands." As for instance where a broker secured a loan for the trustee for the benefit of the estate, the trustee promising to pay the commission out of the trust fund, it was held that the trust estate was not liable, but the trustee was personally. ${ }^{20}$ And so where a note signed by A. B. Trustee, was taken by the payee with knowledge that it was for the benefit of the estate, yet the trustee was held personally liable. ${ }^{20}$ Hill on Trustees states the rule "A trnstee who carries on any trade with the trust assets for the benefit of the cest11 is que trust will be responsible to the creditors, not only to the extent of the trust assets but also with the whole of his own

\footnotetext{
"'" Loring, Trustees Handbook, pp. 25-29; Ames, Cases, $2 d$ E<1., pp. 278-281; Ken. neson, Cases, pp. $14 ; \bullet 152$ • 
property, and he may be made bankrupt and proceeded against in the same manner as any other trader, and it is immaterial that the trade is carried on by him in consequence of an express direction in the trust instrument; although the trust property will doubtless be primarily liable to creditors, and will be first applied so far as it will go in discharge of the liabilities. $\bullet \mathrm{m}$

This of course is directly contrary to the liability of corporate directors, and is so different that, if it could not be modified it would

deter competent business men from accepting such trusts. Can a trustee then exclude such liability by express stipulation to the contrary? It is clear he can. In Shoe and Leather Bank v. TVood,m it was held that there was not personal liability upon the trustees where they had executed a note reading "We as Trustees but not individually promise to pay," signed by themselves "Trustees ;" and it is rnled, in the words of the syllabus in Russe'?' v. Arnold, "No action can be maintained against trustees, holding the property of an unincorporated association, on a contract made by them which by its terms is enforceable only against the property held in trust." $m$ This has been more recently affirm ed..$^{25}$

Upon the stationery of the Massachusetts Gas Companies, printed in red ink, there appears the following, "The name 'lvfassachusetts Gas Companies' is the designation of the Trustees for the time being under an agreement and declaration of trust, dated 1902, and all persons dealing with the Massachusetts Gas Companies must look solely to the Trust property for the enforcement of any claim against the Companies, as neither the Trustees, Officers nor share- holders assume any personal liability for obligations entered into on behalf of he Companies."uo In the Old South Building Trust

deed it is provided that "In every written order, contract or obligation which the Trustees shall give, authorize or enter into, it shall be the duty of the Trustees to stipulate or cause to be stipulated that neither the Trustees nor shareholders shall be held to any personal liability under or by reason of such order, contract or obligation."m In some of the older cases the exemption of the trustee from per- sonal liability was placed upon the right of subrogation of the creditor to the trustees right of indemnity, and to that alone; so that if the trust estate was insolvent, or the trustee exceeded his

... 123 Mass. 148 (1877)

„. 185 Mass. 202 (1904).

.., King v. Stowell (1912) 211 Mass. 246, 251.

"' Sears, Trust Estates etc., p. 320.

"'" Conyngton, Corporate Organization, pp. 548, 556. 
$-53-$

authority the trustee was still personally liable. Perhaps he still is in the latter case, but not in th'e former. ${ }^{20}$

But how about the liability of the beneficiaries? This depends

apparently upon whether they are really and truly, and individually, beneficiaries only, of an existing trust, or whether they are assoc- ciated together in such a way as in fact to be partners engaged in business for profit, the trustees being not really the owners of the property, but in substance and truth the agents of the associated beneficiaries. There has been much consideration given to these matters in Iassachusetts.

In Hoadley v. Commrs, $2 y_{1 / 9}^{9}$ the question was whether transferable shares in a trust were taxable as corporate shares would be, i. e., at the domicile of the owner, or where the trust property was located. I-1eld, the latter, since they were shares in a partnership. Here the parties had "associated themselves to hold property and carry on

business," "as the McKay Sewing Machine Association," but no member was to have any power to make any contract or transact any business for the Association, which was itself to be the equitable owner, and "the general management of the business" was

"vested in an executive committee $* * *$ to be chosen by the whole body of shareholders at a meeting called by the trustee for that purpose."

In Gleason v. M cKay, ${ }^{20}$ the same Association was involved, and the question was whether the Association should be taxed upon all its outstanding shares, as corporations were taxed. It was held not, on the ground it was a partnership, without any corporate franchise, and so not subject to the tax.

In lVhitman v. Porter, h subscribers associated themselves together to buy a ferry boat to be conveyed to one in trust, to be managed by trustees and officers elected annually by subscribers, who were to have transferable shares for their interests in the "Agawam Ferry Co.;" the plaintiff in the case was one of the share- holders, who had advanced money to pay notes given for the pur- chase of the boat and to pay expenses and asked for contribution from the others, over and above their subscriptions to pay the amount due. Held, it was substantially a partnership, and "as between themselves they were ultimately liable in proportion to their interests. But as to creditors, each was liable for the whole."

\footnotetext{
... Sears, Trust Estates, p. 40 et seq.; Loring, Trustees Handbook, p. 35.

:u 105 Mass. 519 (1870)

'"' 134 Mass. $419(1883)$

‥ 107 ?.Jass. 522 (1871)
} 
In Phillips v. Blatch ford/ ${ }^{62}$ money was raised to carry on the business of manufacturing grates, by sale of transferable certificates under deed of trust providing the business was to be carried on by a board of managers of whom the trustee was one, and the others were to be elected by the shareholders. Held to be a partnership.

In Ricker v. Am. Loan \& Trust Co., ${ }^{3}$ another tax case. it was held that where those who provided the money for purchasing and selling cars, to be paid for in ten payments with six per cent interest,

were declared to be an Association with the interests represented by transferable shares, the business to be managed by a boar $<1$ of managers named, subject to removal by the shareholders and others to be elected by them, the title of the property being taken in in trust by an incorporated trust company, a partnership was created,

subject to taxation as other partnerships.

So too, in William v. Boston, $2^{5}$ where a trust was organized to

purchase the site of the Museum of Fine Arts, to be held by trustees, who should issue transferable shares to the subscribers, in whom in meeting assembled, was vested the power to instruct the trustees or remove them, and to alter or amend the declaration of trust, and to direct the tmstees to sell the property, and although the deed specifically stated that neither the shareholders nor the trustees were to be personally liable for any obligations of the Trust, yet it was stated that a partnership for taxation purposes was created. In the later case of Williams v. Milton (infra) it was said this was a mistake, it was a trust and not a partnership.

On the other hand in Mayo v. .Moritz, ${ }^{255}$ an inventor transferred his invention to trustees, who were to issue to him one-ha!f of a specified amount of scrip or trans£erable shares, the other half to be issued to subscribers who should furnish the trustees with money for carrying on the business. The Trustees were to hold, manage and dispose of the invention, as they thought best, and vacancies among trustees were to be filled by the remaining trustees, held this did not constitute a partnership.

The same view is taken in the still more recent case of TVilliams v. M ilton. ${ }^{230}$ This is also a taxation case. The $1 \backslash$ Iassachusetts statute provides that personal property held in trust, shall be taxed to the trustee where the beneficiary resides; and partners shall be jointly taxed in the firm name, where the business is done; the

\footnotetext{
,.. 137 Mass. 510 (1864).

"̈o" 140 Mass. $346(1885)$.

"" 08 Mass. 497 (1911),

""151 Mass. 481 (1890).

.,..2,5 Mass. 1 (1913).
} 
business was done in Boston which sought to tax the Trust as a partnership doing business there.

The trust deed creating this Boston Personal Property Trust, "expressly declared that a trust, and not a partnership is hereby created; that neither the Trustees nor the cestuis que trustent shall

ever be personally liable hereunder as partners or otherwise, but that for all debts the Trustees shall be liable as such to the extent of the Trust Fund only. In all contracts or ins'truments creating liability it shall be expressly stipulated that the cestuis que trustent shall not be liable."

"The Trustees shall have as full power and discretion, as if abso- lute owners, to invest and reinvest the Trust Fund, in personal property," to borrow money to extent of 25 per cent of property and pledge as collateral security any personal property belonging to the Trust Fund; to declare dividends in their discretion; to render an

annual account; to resign,-vacancies to be filled by remaining tmstees; to issue transferable certificates; to alter, add to or terminate the trust with the consent of three-fourths in interest of the cestuis que trustent.

The court by LORING, ]., said: "Where persons associate them- selves together to carry on business for their mutual profit, they are none the less partners because ( 1) their shares in the partnership are represented by certificates which are transferable and transmissible, and because (2) as a matter of convenience (if not of necessity in case of transferable and transmissible certificates) the legal title to the partnership property is taken in the name of a third person. The person in whose name the partnership property stands in such a case is perhaps in a sense a trustee. But speaking with accuracy he is an agent who for the principal's convenience holds the legal title to the principal's property.

After reviewing the Massachusetts cases above referred to, the court points out that the difference between the partnership cases, ( the Hoadley, Whitman, Gleason, Phi/lips, Ricker and Williams cases), on one hand and Mayo v. ,l,forit::: ( the patent case) on the other, lies in the fact that in the former cases the certificate holders are associated together by the terms of the "trust" and are the principals whose instructions are to be obeyed by their agent who for their convenience holds the legal title to their property. The property is their property. They are the masters. While in Mayo

v. $M$ orit $: \because$ on the other hand there is no association between the certificate holders. The property is the property of the trustee 5 and the trustees are the masters. All that the certificate holders in Mavo v. Morit:; ha $<1$, was a right to have the property managed by the 


\section{$-58-$}

managers ( the defendants, appellant) was not that of principal and agent (though doubtless fiduciary) but that the managers themselves became the principals in any contract which they might make."

There are many other cases to like effect. It seems therefore that the usual personal liability of the trustees can be excluded by express provision brought home to every one dealt with; the cestuis qlte trust, are not partners if the ownership and control of the fund

are left with the trustees; and by express provision brought home to a dealer the Trust Fund alone can be made liable for the obliga- tions of the trust.

I have referred to the provisions relating to capital stock of a corporation, and pointed out some of the discordant theories in reference thereto. It has been, in the main, a struggle between persons on the one hand who have wished to capitalize visionary prospective profits before their dreams were in fact realized, and if

disaster came, to get out from under, with some one else in possession of the hot air bag, $2^{62}$ and the State's effort on the other hand to make the actual capital, in the beginning come up to the manifesto, or supplement this by other liabilities that frequently work unnecessary hardship upon honest business. ${ }^{2}{ }^{3}$ It certainly cannot be said that the schemes so far devised havebeen satisfactory. Upon the one hand they have been insufficient to accomplish their real purpose; and upon the other, have been too inflexible and inelastic to encourage- honorable and legitimate enterprise. The careful investor in shares has difficulty to ascertain from statements of capital stock much that aids him in getting at real values, while the careless one is almost certain to be misled. The creditor also is in much the same predicament. The really careful investor or creditor, relies not upon the capital stock statements but upon the actual property and course of business of the particular in stitu tion. ${ }^{264}$ The Trust for the most part proceeds upon a like theory. If one deals with a Trust in reference to the Trust, it is made his duty in the absence of express provisions otherwise, and if he has notice that he must look to the Trttst property alone for security, to ascertain just what that property is, without regard to any amount of nominal shares that may be issued against it. ${ }^{265} \mathrm{In}$ other words the shares, few or many, have nothing particularly to do with the property, but are only the

262 See dissenting opinion of Chief Justice Fuller in Handley v. Stutz (1891) 139 U.S. 417,:: Wilgt,s, Cases, 1923, 1932•

.. Machen, A. W., "Do Corporation laws allow sufficient freedom to commercial enterprise?" Maryland Bar Ass'n Report, 1909, pp. 78-98.

:et See Cook, Corporations, 7th Ed. §§ 46-47.

... Kisch v. Tozier (1894) 143 N. Y. 390, 42 Am. St. R. 729, note 733 
method of indicating aliquot parts of the fund for the convenience of the owners. The investor and the creditor both are expected to act as business men do, and are required to do, when they are deal- ing with individuals, that is, rely upon their own investigation, knowledge and judgment.

Different people will take different views as to the best policy, in this regarct. ${ }^{00}$ Recently New York has provided for the issue of corporate shares without par value, and has recognized the duty of investor and creditor alike to rely upon his own judgment, instead of upon the uncertain meaning of a fixed capital stock. ${ }^{267}$ The efficiency and validity of blue sky laws are yet "in nubibus," and make ccrporate capitalization still more intricate,-and cloudy. ${ }^{268}$ While the right of inspecting corporate books by shareholders 1s now generally recognized, without any actual controversy being involved. such right, in the case of Trusts, can be fully recognized or regulated by the trust deed provisions, as the stautory or common law rules permit in the case of corporations.

F. In an article in the Atlantic Jlfontlal 's 'a short time ago Mr.

STETSON,

There are, said he ( 1) Taxation,-organization tax, franchist? or continuing tax, property tax, transfer tax, foreign state tax, and Federal tax, nearly all of which are now imposed upon corporations, and in addition thereto the shares of shareholders are frequently taxecl to the owner, i'f not in the creating state, certainly to him when he lives in another state. ${ }^{270}$ So, too, the franchise tax maybe imposed at home, and another privilege tax in each of the states where the corporation does business, and these may be and frequently are higher than domestic corporations in the same business

pay, for a corporation does business, other than interstate commerce, in a foreign state. by sufferance, comity as it is called,rather than by rightm Property of course is taxed wherever it is,

,.. See Burton, T. E., Corporations and the State (1911); Stock \Vatcring, \V. Z. Ripley, 06 Pol. Sci. Q. 98-121 (1911); Capital of Corporations, G. W. Wickercham, 22

Harv. Law Rev. 319-338 (1909); Overcapitalization, 38 Natl. Corp. Rep. 59 (1909); Stockwatering, i2 Bench and Bar, 43 (1908); Williams v. McClave (1914) 148 N. Y. S. !J.1-

""'" Shares \Vithout Nominal or Par Value, Victor Morawctz, 26 Harv. Law Rev. 729 (1913).

"'"Blue Sky Laws, F. A. Updike, 7 Am. Pol. Sci. Rev. 230-237 (1913); Alabama \&

N. O. 'fransp. Co. ct al. v. Doyle (1914) 210 Fed. 173.

"'"'no· Atl. Monthly, p. 27 ct seq. (1912), July),

r.o 2 Wilgus, Cases, pp. 1370-1391; Farrington v. Tennessee (1877) 95 U. S. 679, 2

VVilgus, Cases, 1370.

271 Bank of Augusta v. Earle (1839) 13 Pct. (38 U. S.) 519, 2 Wilgus, Cases, 148o; Manchester

Fire Ins. Co. v. Herriott (1899) 91 Fed. 7rr, a Wilgus, Cases, 1498, note 1502. 


$$
-60
$$

but here the fiction that personal property follows the owner, is often applied much more rigorously to corporations than to indi- viduals. Shares are also subject to an inheritance tax, in the state where the deceased lived, in the state where the corporation is in- corporated, and according to some decisions also where the shares are to be transferred. The transfer tax can be imposed wherever the transfer is to be made. ${ }^{272}$ The Federal tax is now an income tax, and of course would apply to the income of a Trust as well as a corporation. The Supreme Court however held that the income tax of 1909, applied only to such associations "as are organized under some statute, or derive from that source some quality or benefit not existing at the common law," and Trusts were not so

organized and have no such quality. ${ }^{273}$ In Massachusetts after much variety of opinion, the Supreme Judicial Court has finally ruled that

these institutions can be subjected to an excise tax under their constitution, similar to corporations. ${ }^{3}$ Trust property is usually taxed only to the trustee, who may indemnify himself out of the trust estate.

:Mr. STETSON points out also (2) that corporations are not protected under the 4th and 5th amendments as natural persons are, with special reference to divulging incriminating information, discrimina-

tion against them, as to terms of doing business, and enforcing claims. So also under the reserved power to repeal or amend cor- porate charters, many limitations and restrictions upon a corpora- tion's power to contract can be and are imposed that would not be valid if imposed upon citizens of the United States.m So a foreign corporation as a creditor, unless it has entered a state and complied with its laws in reference to doing business in the state, is not a person within the jurisdiction, so as to be protected under the

„... Morrison v. Manchester (1879) 58 N. H. 538; Fowler v. Campbell 100 Mich. 398; City of Detroit v. Lewis, 109 Mich. 155, 32 L. R. A. 439; Mills v. Thornton, 26 111. 300, 79 Am. Dec. 377; Matzenbaugh v. People, 194 111. 108, 88 Am. St. R. 134; Latrobe v. Mayor, 19 Md. 13; Corry v. Baltimore, 96 Md. 310, 196 U. S. 466, 25 S. C. 297; Tappan v. Merchants' Bank, 19 Wall (U. S.) 490; Merriman's Estate, 147 Mich. 630; Estate of Palmer, 183 N. Y. 238; In re Ames Estate (1913) 141 N'. Y. S. 793; People $v$. Union Trust Co., 255 Ill. 168; Matter of Cooley, 186 N. Y. 220.

${ }^{271}$ Eliot $v$. Freeman (1911) 220 U. S. 178

27 In re Opinion of Justites (1908) 195 Mass. 607, 84 N. E. 490; In re Opinion of Justices (1911) 208 Mass. 616, 94 N. E. 1043; Compare S. S. White Dental Mfg. Co. v. Commw. (1912) 212 Mass. 35, 98 N. E. 1056 (Corp.); Keystone IVatch Co. v. Commw.

(1912) 212 Mass. 50, 98 N. E. 1063 (Corp.); Farr Alpaca Co. v. Commw. (1912) 212 Mass. 156, 98 N. E. 1078 (Corp.); Baltic Min. Co. v. Commw. (1913) 231 U. S. 68, 34 S. C. 15.

= State v. Nashville etc. Ry. Co. (1911) 124 Tenn. 1, 135 S. W. 773, Ann. Cas. 1912 D. 805; Hale v. Henkel (1906) 201 U.S. 43; Wilson v. U.S. (1911) 221 U.S. 361; McGuire v. Railway Co. (1906) 131 Ia. 340. 


$$
\text { - } 61-
$$

clause that says "no state shall deny to any person within its jurisdiction the equal protection of the laws." ${ }^{276}$ In almost all these particulars, trustees being citizens of the United States and entitled to all the privileges and immunities of citizens in the several states, would be protected more fully than a corporation.m So too many states attempt to exclude corporations doing business in the state from suing in the Federal courts, and while they cannot actually exclude them from the Federal Courts, they may ou\& the offending corporation from the state. ${ }^{278}$

:Mr. STETSON also points out (3) the very great and unjust toll that is paid by corporations in litigation because of prejudice against them, exhibited by juries and legislators. In some degree at least this would be less pronounced in the case of a Trust, where responsible local citizens of standing were the trustees.

Upon the public side it was noted in the beginning that one of the

crying weaknesses of corporations was the impersonal character, and

the lack of individual personal responsibility, especially toward the public, that characterized it, and its actions. It might seem that here the Trust would be superior; and it is more than probable that so far as the relation of the Trustee toward the beneficiaries, is concerned, there is under the rules 'of courts of Equity, a much more positive and direct feeling of personal responsibility.

Toward the public, however, this may be doubted, for we have the experience that all of our great industrial combinations, good and bad, have almost without exception originated as Trusts, under Trust deeds such as we have been describing ; 279 and from this form, held by the New York Court of Appeals, in the Sugar T rust ${ }^{280}$ case to be illegal as a partnership contrary to the right of a corporation

to be a member of such, and by the Supreme Court of Ohio in the Standard Oil Case to be an institution in unlawful restraint of trade, ${ }^{281}$ those $\mathrm{v}$-:ho then saw the handwriting on the wall fled in hope to find legal shelter in the corporate form, only to find their

"' Blake v. McClung (1900) 176 U. S. S9, a Wilgus, Cases, 2045: (1898) 172 U. S. 239, 2 Wilgus, Cases, 2036.

m Farmers Loan \& Trust Co. v. Chicago etc. Ry. Co. (1886) 27 Fed. 146; Roby

v. Smith (1891) 131 Ind. 342, 20 N. E. 1093: Scars, Trust Estates etc., 194.

211 Doyle v. Continental Ins. Co. (1876) 94 U. S. S3S, 2 Wilgus, Cases, 1491: Harrison v. St. Louis \& S. F. R. Co. (1914) - U. S. -, 34 S. C. 333

${ }^{211}$ See I Wilgus, Cases, pp. 957,984. Sec cases in 212 1llass., and 231 U. S. in note 274 above

"'"People "'· North River Sugar Ref. Co. (1890) 121 N. Y. 582, 1 Wilgus, Cases, 100, note 109.

"'State v. Standard Oil Co. (1892) 49 0. S. 137, 34 Am. St. R. 541. 
hope in vain. ${ }^{282}$ Neither trust nor corporate form where restraint

of trade is the end of the organization, can stand the searching power of the government to destroy either under the common law or under the anti-trust acts. ${ }^{283}$

- Massachusetts has through Commissioners made investigations of these Express Trusts, and after two reports, enacted legislation providing for the filing with the Railroad Commission of all deeds of trust for such Associations, and in the case of Trusts for owning shares in railway, street railway and electric railway companies, or which are managed by the same parties, making annual reports to, and making them subject to examination by, the Railroad Commis-

sion. The same power is given also to the Gas Commission in reference to gas, electric light, and power companies.

If the foregoing review is accurate, it would seem that, largely because of the variety, uncertainty, and confusion arising from conflicting legislative provisions, the Tmst form of organization, at

least upon the private side, is more simple, certain, consistent and yet flexible, and perhaps with even more satisfactory safeguard. available both to the investor and the creditor, than is the corpora- tion.

Upon the public side, however, so far as control is concerned, the State can reach an offending corporation more directly and posi- tively, notwithstanding the Trust form of organization was abandoned for the corporate form, with the belief that in that way

anti-trust laws could be evaded.

So far as any feeling of direct personal responsibility toward the public as a whole rS c;oncerned, there does not seem to be much difference. The psychology of the group mind seems to be inherently different from that of a single individual. It will seek and accomp- lish ends from which individuals will shrink. As the non-explosives, glycerine, nitric and sulphuric acids and saw-dust mixed, make the explosive dynamite, so does the combination of the intelligent, the stupid, the selfish and unselfish, the honest and the dishonest, into one group, give a resultant that when quiescent usually does much better than the worst, yet from hidden powers often does much worse than the worst. ${ }^{286}$ Undoubtedly much could be done to make

\footnotetext{
$\mathrm{m}$ Distilling \& Cattle Feeding Co. v•. People (1895) 156 Ill. 448, 1 Wilgus, Cases, 978.

,.. Northern Securities Co. v. U. 5. (1903) 193 U. 5. 200; Standard Oil Co. v.

U. S. (1910) 221 U. S. 1; L'. S. v. Am. Tobacco Co. (1910) 221 U. S. 106 ... Sec chapters 454, 509, and 596 of Public Acts of 1913.

211 Distilling and Cattle Feeding Co. v. People (1895) 156 Ill. 448, 47 Am. St. R. $1 \backslash$ Vilgus, Cases, 978.

"'" LeBon, The Crowd, pp. 2-44.
} 
our corporation laws, more simple, certain and flexible; and a properly worked out Federal incorporation law would help corpora- tions with extensive business in many respects, and furnish a model for state legislation.

IVhen laws are uncertain, or unduly hamper legitimate enterprise,

bright minds will invent methods to accomplish unexpected ends. In the early years of our history, there was great prejudice against the incorporation of banks, and there were either no laws permi tting it or if there were any, they were such as were difficult to comply with. The brilliant services of Alexander Hamilton, and of Aaron Burr were called in requisition to devise plans for the institution of banks in New York City. Hamilton drew up a masterly paper which

with a- few words changed-directors to trustees, shareholders to

beneficiaries, and a few others, would still be a model form for a Trust for business purposes, such as we have been considering, an $<1$ which was the constitution of the Merchants Bank for 20 years, until the legislature forbade banking in any but the corporation form. On the other hand Aaron Burr engineered a bill through the New York legislature to incorporate a company to supply the city of Kew York with water, and with authority to use its surplus capital "in any way not inconsistent with the laws and constitutions of the

United States and New York." Under ithis charter, so it is stated, the Manhattan Bank has been carrying on business for 115 years. ${ }^{288}$

These perhaps are typical illustrations as to what lawyers are calied upon to' do, and the methods sometimes resorted to. The one statesman-like, constructive, and within the law. The other unstatesman-like, destructive, and if within the law at all, only so by taking advantage of its uncertainty, to thwart the expressed will of the people.

Perhaps these things can never be wholly overcome until men are made over. All production is the result of the combination of forces within man, with forces and •things outside him, of persons and property. From the beginning of time some men in whom the sense of brotherhood was latent or unborn, have always classed other men as external things to be used or exploited as other property, and have considered it proper to take all that their strength, their wit or their cunning enabled them to take; others have believed that they should take no more from the common fund than thev had contributed to it; still others that -they should contribute to it all their ability and their skill would enable them to

\footnotetext{
"'"Hamilton's \Vorks, vol. 7, pp. 838-844; Sears, Tntat Estates, etc., p. 341.

"'Century Magazine, May, 1899; Parton'• Life of Burr, p. 238.
} 


$$
-6 \cdot 4-
$$

do, and take from it only what they needed. There is no doubt but that the trend of the ages has been practically from the first of these toward the second, and perhaps in the more recent years of -the Christian era, there has been a trend ideally at least, if not much practically, toward the third. As one or the other of these ends are dominant so will the nature and the administration of the laws be. And so will the institutions founded upon them be. But none will be perfect until men are perfect.

Uni.versity of Michigan.

H. L. WILGUS. 
syrafy Oorp ratiens and

mir. un. xpreas trueta as uelnees rganiz\&tiona

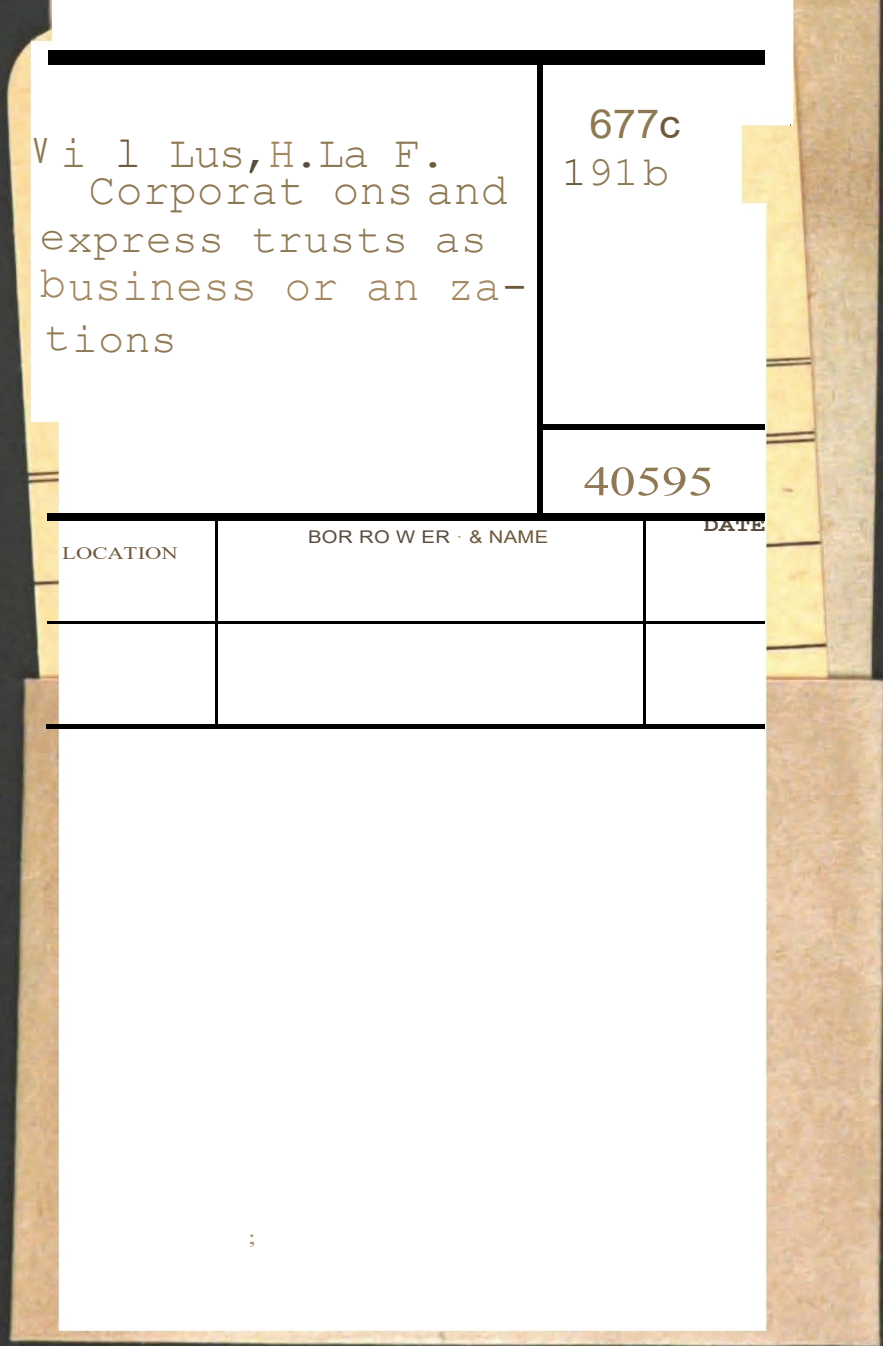

